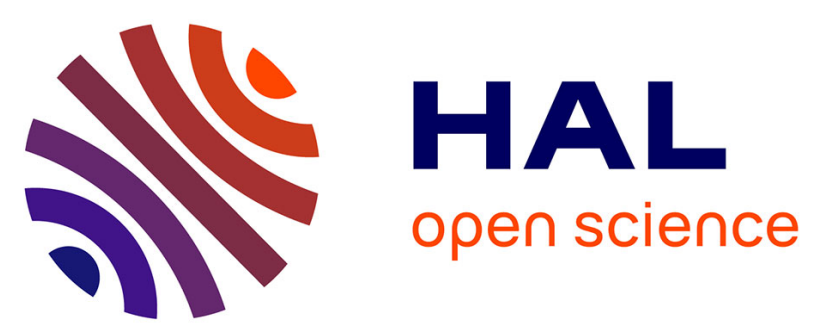

\title{
Volcano flank instability in the Lesser Antilles Arc: Diversity of scale, processes, and temporal recurrence
}

Georges Boudon, Anne Le Friant, Jean-Christophe Komorowski, Christine Deplus, Michel P. Semet

\section{- To cite this version:}

Georges Boudon, Anne Le Friant, Jean-Christophe Komorowski, Christine Deplus, Michel P. Semet. Volcano flank instability in the Lesser Antilles Arc: Diversity of scale, processes, and temporal recurrence. Journal of Geophysical Research : Solid Earth, 2007, 10.1029/2006JB004674 . insu-01289733

\section{HAL Id: insu-01289733 \\ https://hal-insu.archives-ouvertes.fr/insu-01289733}

Submitted on 17 Mar 2016

HAL is a multi-disciplinary open access archive for the deposit and dissemination of scientific research documents, whether they are published or not. The documents may come from teaching and research institutions in France or abroad, or from public or private research centers.
L'archive ouverte pluridisciplinaire HAL, est destinée au dépôt et à la diffusion de documents scientifiques de niveau recherche, publiés ou non, émanant des établissements d'enseignement et de recherche français ou étrangers, des laboratoires publics ou privés. 


\title{
Volcano flank instability in the Lesser Antilles Arc: Diversity of scale, processes, and temporal recurrence
}

\author{
Georges Boudon, ${ }^{1}$ Anne Le Friant, ${ }^{1}$ Jean-Christophe Komorowski, ${ }^{1}$ Christine Deplus, ${ }^{1}$ \\ and Michel P. Semet ${ }^{1}$ \\ Received 4 August 2006; revised 29 December 2006; accepted 12 March 2007; published 14 August 2007.
}

[1] The 1997 Boxing Day collapse, a remarkable feature of the ongoing eruption of Soufrière Hills on Montserrat, has prompted new interest in the study of volcano stability in the Lesser Antilles. Building on a few cases documented in the literature, we have now identified at least 47 flank collapse events on volcanoes of the Caribbean arc where this type of behavior is characteristic and repetitive. About 15 events occurred on active volcanoes within the last 12,000 years. In the northern part of the arc, flank collapses are repetitive, do not exceed $1 \mathrm{~km}^{3}$ in volume, occur in all directions, and are promoted by intense hydrothermal alteration and well-developed fracturing of the summit part of the edifices. In contrast, infrequent but large sector collapses, with volumes up to tens of $\mathrm{km}^{3}$, are typical of the southern volcanoes. They are always directed to the west as a result of the high overall slopes of the islands toward the deep back-arc Grenada Basin. Because Caribbean islands are small, a large part of the resulting debris avalanches have flowed into the sea thus contributing voluminous and sudden inputs of volcaniclastic sediments to the Grenada Basin. Deposits from such submarine flows have been identified during the recent AGUADOMAR and CARAVAL oceanographic cruises and traced to their source structures on land. Edifice collapses have a major influence on subsequent volcanic activity but also are of high concern because of their tsunamigenic potential.

Citation: Boudon, G., A. Le Friant, J.-C. Komorowski, C. Deplus, and M. P. Semet (2007), Volcano flank instability in the Lesser Antilles Arc: Diversity of scale, processes, and temporal recurrence, J. Geophys. Res., 112, B08205, doi:10.1029/2006JB004674.

\section{Introduction}

[2] Catastrophic volcano flank collapses are increasingly recognized as a "normal" process in the construction and destruction of volcanic edifices [McGuire, 1996]. They play a significant role in the evolution of volcanic edifices, on the dynamics of subsequent eruptions and are a significant component of volcanic hazards. Since the 1980 eruption of Mount St. Helens [Lipman and Mullineaux, 1981], collapse events have been recognized on a large number of volcanoes in different geodynamic settings [Siebert, 1984; McGuire, 1996]. Most studies were carried out on land only. The recognition of flank collapse events is ideally based on mapping debris avalanche deposits (DADs) with a characteristic morphology and structure that can be traced to a generally horseshoe-shaped collapse depression. Often, however, only one of these two components is recognized because subaerial DADs have been eroded or because the depression has been filled subsequently by erupted products. This is frequently the case for older events or for volcanoes with high magma production rates. On island

\footnotetext{
${ }^{1}$ Equipe Géologie des Systèmes Volcaniques, Institut de Physique du Globe de Paris, Centre National de Recherche Scientifique, Paris, France.

Copyright 2007 by the American Geophysical Union. 0148-0227/07/2006JB004674\$09.00
}

volcanoes, debris avalanches have often partly or almost entirely entered the sea so that their characteristics and extent can only be determined from marine geophysical data (swath bathymetry, backscatter data, $3.5 \mathrm{kHz}$ echo sounder and seismic reflection profiles). Underwater deposits may cover hundreds to thousands of $\mathrm{km}^{2}$. As a matter of fact, the most voluminous events were recognized on oceanic islands: Hawaii [Lipman et al., 1988; Moore et al., 1989], La Réunion [Lénat et al., 1989; Labazuy, 1996, Oehler et al., 2004], and on the Canary Archipelago [Holcomb and Searle, 1991; Watts and Masson, 1995; Urgeles et al., 1997; Krastel et al., 2001]. Flank collapses can involve very different volumes of material, from tenths to hundreds or even thousands of $\mathrm{km}^{3}$. They can occur several times on the same volcano and may repeat at small time intervals (hundreds of years) mainly when they mobilize small volumes of material as is the case for Augustine volcano in the Aleutian archipelago [Béget and Kienle, 1992] or for Sheveluch in Kamchatka [Belousov et al., 1999]. When flank collapses occur on volcanic islands, part or most of the debris avalanches can enter the sea and produce catastrophic tsunamis.

[3] In the Lesser Antilles, Roobol et al. [1983], Wadge [1985], Wadge and Isaacs [1988], Vincent et al. [1989], and Mattioli et al. [1995] have proposed that horseshoe-shaped depressions observed on the active volcanoes of Montserrat, 
Dominica, St. Lucia, St. Vincent and Martinique, originated by sector collapse. These authors did not provide field evidence for associated debris avalanche deposits. Boudon et al. [1984, 1987] identified two events, dated at 11.5 and $3.1 \mathrm{ka}$, on the active La Grande Découverte-La Soufrière volcano in Guadeloupe and showed that their associated DADs can be traced back to their source horseshoe-shaped collapse structures. More recently, a partial collapse of the southern part of the summit crater and of the active lava dome of Soufrière Hills, Montserrat, was witnessed and closely studied during the eruption in December 1997 [Sparks et al., 2002; Voight et al., 2002; Young et al., 2002].

[4] A geophysical survey of the submarine flanks of the Lesser Antilles islands from Montserrat to St. Lucia was obtained during the AGUADOMAR oceanographic cruise in 1999 (R/V L'Atalante). Several chaotic mass flow deposits were recognized that we interpreted as debris avalanche deposits [Deplus et al., 2001]. A series of on-land surveys were subsequently performed in order to complement older observations and verify the on-land extent of the debris avalanche deposits and link them to collapse depressions. The correlation of the marine and the on-land data has allowed us to identify and characterize flank collapse events on most of the active volcanoes of the arc [Le Friant, 2001; Le Friant et al., 2002, 2003, 2004] and shows that on some of the volcanoes, collapses have been repetitive. During the CARAVAL oceanographic cruise also on $\mathrm{R} / \mathrm{V}$ L'Atalante in 2002 we extended the geophysical survey to the western part of St. Vincent and the Grenadines, acquired highresolution seismic reflection profiles perpendicular to the emplacement axis of the debris avalanche deposits and performed a series of piston cores for the study of the tephrochronology and the submarine sedimentological aspects west of the islands and into the Grenada Basin from St. Vincent to Montserrat.

[5] In this paper we present an overview of the studies we have undertaken on land and offshore on flank collapses in the Lesser Antilles arc. We have now identified 47 flank collapse events on the active volcanoes but also on older edifices of which about 15 occurred in the last 12,000 years. We describe these events and discuss their origin, their effects on the evolution of the edifices and on the sedimentation in the back of the arc. We also discuss the hazards produced by repetitive collapses or when they mobilize large volumes of material that suddenly enter the sea.

\section{Geological Setting}

[6] The Lesser Antilles arc results from the subduction of the Atlantic Ocean lithosphere beneath the Caribbean plate. It has a curved shape and extends from $12^{\circ}$ to $18^{\circ} \mathrm{N}$. Arc volcanism has been active since $40 \mathrm{Ma}$ [Martin-Kaye, 1969; Bouysse et al., 1990]. North of Dominica, the arc is divided into two groups of islands. In the eastern and older group, volcanoes are extinct and, on several islands, covered by a thick carbonate platform. Active volcanoes are located in the western group of islands and have been active since $20 \mathrm{Ma}$. South of Dominica, the two branches of the arc merge and deposits of the older arc underlie the recent one. This southern part of the arc is bordered to the west by the $3000 \mathrm{~m}$ deep back-arc Grenada Basin (Figure 1).
[7] Twelve volcanoes, active in Holocene times, are located in the ten major islands of the younger arc. In the largest islands, active volcanoes generally belong to N-S elongated chains of successively active edifices. We present here a geological overview of the islands we have surveyed.

[8] The island of Montserrat is composed of three main volcanic centres. From north to south: Silver Hills ( $\sim 2.6$ to $\sim 1.2 \mathrm{Ma}$ ), Centre Hill (at least $\sim 950$ to $\sim 550 \mathrm{ka}$ ) and South Soufrière Hills-Soufrière Hills (at least $\sim 170 \mathrm{ka}$ to the present) [Harford et al., 2002]. Soufrière Hills started to erupt in 1995 after 320 years of dormancy. Over a decade, this remarkable eruption (one of the largest and longest historical eruptions in the Lesser Antilles) has erupted about $0.5 \mathrm{~km}^{3}$ of andesite magma during three main periods of dome growth (November 1995 to March 1998, November 1999 to July 2003 and August 2005 to present) [Robertson et al., 2000; Sparks and Young, 2002; Hincks et al., 2005]. The eruption has been dominated by the generation of pyroclastic block-and-ash flows and associated tephra fall resulting from gravitational collapse of the dome during growth periods as well as during pauses in dome growth that have lasted from days to months. Pumiceous pyroclastic flows were also generated from column collapse during periods of explosive vulcanian activity in 1997. A large dome collapse occurred on 12 July 2003 when about $90 \%$ $\left(210 \times 10^{6} \mathrm{~m}^{3}\right)$ of the remaining dome produced since 1995 collapsed during a major explosion [Herd et al., 2005]. A small dome formed after this eruption in the collapse scar. Cessation of dome growth started early August 2003 and has continued until August 2005, when a new phase of dome growth began. A new dome collapse occurred on 20 May 2006 and was immediately followed by another phase of ongoing dome growth.

[9] In the Guadeloupe archipelago, the volcanically active western island of Basse-Terre is composed of seven volcanic complexes that form a continuous $55-\mathrm{km}-$ long volcanic chain trending NNW, up to $25 \mathrm{~km}$ in width, and reaching a maximum elevation of $1467 \mathrm{~m}$ on the active Soufrière lava dome, the highest peak of the Lesser Antilles. The oldest Basal Complex in the northern part was active from about 3 to $1 \mathrm{Ma}$ [Samper et al., 2004, 2007]. The Chaîne Axiale and the Bouillante Complex were active from 1 to $0.25 \mathrm{Ma}$. The most recently active composite volcano of La Grande Découverte-La Soufrière (circa $0.3 \mathrm{Ma}$ to the present) is located in the southern part of this chain and north of the 0.5 Ma old Monts Caraibes complex at the extreme south of the island. The Soufrière lava dome was formed during the last magmatic eruption dated at 1530 A.D. (G. Boudon, manuscript in preparation, 2007). Historical eruptive activity since the arrival of the settlers in 1635 A.D. has consisted exclusively of 6 phreatic explosive eruptions [Boudon et al., 1988; Komorowski et al., 2005], with minor events in 1690, 1812, 1836-1837, 1956 [Barrabé and Jolivet, 1958] and major events in 1797-1798 and recently in 1976-1977 [Feuillard et al., 1983].

[10] Dominica is the only island in the Lesser Antilles where several recently active volcanoes are present. The entire island is composed of a continuous chain of volcanic edifices [Lindsay et al., 2005b]. From north to south, Morne au Diable volcano has an active "Soufriere", Morne Diablotin has also active fumaroles on the northwestern flank of 


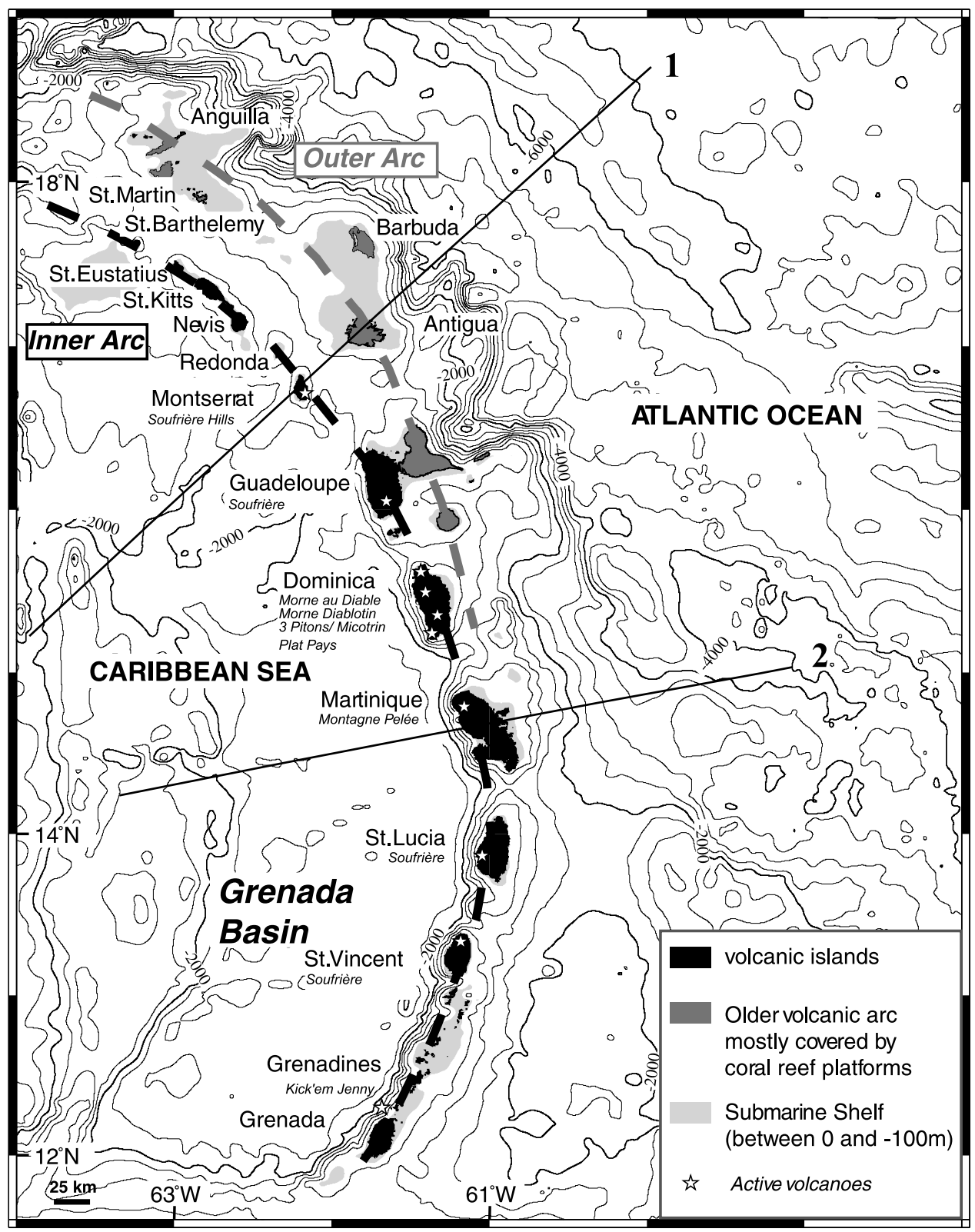

Figure 1. Lesser Antilles arc. Predicted bathymetry is from Smith and Sandwell [1997]. Contour interval is $500 \mathrm{~m}$, and $2000 \mathrm{~m}$ isolines are in bold. Volcanic islands are black, and subaerial coral reef platforms are dark gray. The $100 \mathrm{~m}$ depth submarine shelf is light gray. Lines 1 and 2 indicate the location of two profiles through the arc shown on Figure 16.

the edifice; Morne Trois Pitons and Morne Micotrin have had recent explosive activity with two phreatic explosions in the Valley of Desolation (1863 and 1997). The Plat Pays volcanic complex occupies the extreme south of the island. It is the youngest complex with two prominent recent lava domes, Morne Crabier and Morne Patate ( 490 years old), and a very active fumarolic field [Roobol et al., 1983; Wadge, 1985; Lindsay et al., 2003].

[11] Montagne Pelée, the active volcano of Martinique, is located in the northern part of the island. It is one of the most active of the arc and is sadly remembered for the devastating 1902-1905 and the 1929-1932 dome-forming eruptions [Lacroix, 1904; Perret, 1937]. The destruction of the capital city of St. Pierre and the village of Morne Rouge, in the early phases of the 1902 eruption, caused about 30,000 deaths and stirred widespread international concern over the disasters caused by explosive volcanoes. Prior to these magmatic eruptions, only two phreatic eruptions occurred in 1792 and 1851 for the historic period since 1635 A.D. Montagne Pelée is located between two older and extinct edifices: Mont Conil to the north and Morne Jacob-Pitons du Carbet to the south. The southern part of Martinique only shows Tertiary and older eroded volcanic edifices [Westercamp et al., 1989].

[12] On St. Lucia the recent activity is located in the southwestern part of the island on the Soufriere Volcanic Centre inside the Qualibou structure. Several lava domes were emplaced in the structure, as recently as about 
39,000 years ago. A very active fumarolic field is present in the central part of the structure. The last historical explosive event was phreatic and occurred in 1760 A.D. [Tomblin, 1965; Wright et al., 1984, Lindsay, 2005].

[13] The active Soufriere volcano on St. Vincent is located in the northern part of the island. Like Montagne Pelée it is one of the most active of the arc with three eruptions during the last century. In 1902-1903, pyroclastic flows from an open-vent explosive eruption caused the death of 1500 inhabitants [Anderson and Flett, 1903]. In 1971, a lava dome was emplaced through the water lake inside the summit caldera [Aspinall et al., 1973]. This most recent phase of activity culminated in $1979-1980$ by a new small open-vent explosive event followed by the growth of a new lava dome inside the caldera [Shepherd et al., 1979]. Mostly very dissected old volcanoes occur in the southern part of the island.

[14] On Grenada, the last activity of Mount St. Catherine Centre could be of Holocene age [Robertson, 2005]. However, $9 \mathrm{~km}$ north of Grenada, the submarine Kick'em Jenny volcano is the most active of the Lesser Antilles arc as a whole with 12 reported eruptions since 1939 [Robson and Tomblin, 1966; Smith and Shepherd, 1993]. The last submarine eruption occurred in December 2001 [Lindsay et al., 2002; Lindsay and Shepherd, 2005].

\section{Methodology}

[15] We base our work on morphological, geological and marine geophysical data. The marine data were gathered during two French oceanographic cruises on the $\mathrm{R} / \mathrm{V}$ L'Atalante. During the AGUADOMAR cruise (December 1998 to January 1999) we collected Simrad EM12D swath bathymetry and backscatter data, $3.5 \mathrm{kHz}$ echo sounder profiles, gravity, magnetic and six-channel seismic reflection data from Antigua to St. Lucia and up to $75 \mathrm{~km}$ from the coastlines [Deplus et al., 2001]. During the CARAVAL cruise (February 2002), which extended from Montserrat to St. Vincent, we collected similar data as well as seismic profiles with a higher resolution using a 24-channel streamer and towing streamer and guns at lower immersion depth [Deplus et al., 2002]. We also obtained some 40 sediment piston cores and a dredge sample. Navigation was achieved using Starfix differential GPS during AGUADOMAR and GPS with no degradation during CARAVAL thus allowing a ship position accuracy of a few meters for both cruises. Swath bathymetry and backscatter data were processed using the CARAIBES software developed by IFREMER. We constructed digital elevation models (DEM) with reso- lutions of 50, 100 and $200 \mathrm{~m}$ depending on the depth of the seafloor and mosaics of acoustic imagery. For both cruises, the multichannel seismic reflection data were filtered, stacked and migrated using seawater velocity and the "Seismic Unix" software [Cohen and Stockwell, 1996].

[16] Morphological analysis of the islands was performed using available digital topography and air photos. On Montserrat we used a $10 \mathrm{~m}$ resolution planimetric DEM, derived from air photos taken prior to the ongoing eruption and provided by $\mathrm{G}$. Wadge. We used the $50 \mathrm{~m}$ resolution planimetric DEM from the French National Geographic Institute (IGN) for Martinique and Guadeloupe. A $50 \mathrm{~m}$ and $100 \mathrm{~m}$ resolution planimetric DEM combining swath bathymetry and subaerial data has been prepared for Montserrat and Martinique, respectively [Harford, 2000; Le Friant et al., 2003, 2004]. In the last several years, on-land geological investigations of horseshoe-shaped structures and DADs were carried out by some of the authors.

[17] The analysis of combined geological and geophysical data sets on land and offshore forms the basis of our identification of flank collapse events (Figure 2). Criteria for the identification of offshore DADs from marine data have been developed by several authors in different contexts [e.g., Moore et al., 1989; Watts and Masson, 1995]. We used these criteria in the analysis of data obtained during the AGUADOMAR and CARAVAL cruises. Deplus et al. [2001] report on the preliminary identification of offshore deposits from several volcanoes of the lesser Antilles arc. On bathymetric data, DADs display a typical hummocky morphology with numerous megablocks. Offshore from Dominica, for example, megablocks reach $2.8 \mathrm{~km}$ in length and $240 \mathrm{~m}$ high nearshore (Figure 2). Backscatter values depend on the absorption efficiency of the seafloor but also on the incidence of the beam relative to the local slope. On backscatter profiles, megablocks display patches of high reflectivity [Moore et al., 1989; Deplus et al., 2001]. They are the result of both contrasting acoustic responses of the lava blocks and the fine products surrounding them, and of the angular shapes of the blocks which provide facing slopes relative to the beam geometry. On $3.5 \mathrm{kHz}$ acoustic profiles, the DADs display a typical signature of rough topography with hyperbolic reflections [Lipman et al., 1988; Watts and Masson, 1995; Urgeles et al., 1997] which contrasts with that of parallel reflectors obtained from sea bottom sediments. Finally, on the seismic reflection profiles, DADs display chaotic reflectors with large energy diffraction, which contrast with subhorizontal reflectors corresponding to the parallel-bedded sediments. Older DADs are recognized by their layered sedimentary cover.

\footnotetext{
Figure 2. Criteria for the identification of flank collapse events. (a) Geological data. (top left) Rims of horseshoe-shaped structures are identified on the basis of topographic discontinuities and direction of the drainage system (e.g., Montserrat: English's crater and South Soufrière structures). (top right) Debris avalanche deposits (DADs) are characterized by megablocks of massive lavas with jigsaw cracks structures (e.g., Plat Pays volcanic complex, Dominica) or hydrothermalized products (e.g., Montagne Pelée, Martinique). (b) Geophysical marine data. The typical hummocky morphology with numerous megablocks and the morphological fronts of DADs are recognized by bathymetric data. On backscatter profiles, megablocks display patches of high reflectivity (e.g., Plat Pays volcanic complex, Dominica). On $3.5 \mathrm{kHz}$ acoustic profiles, the DADs display a typical signature of rough topography with hyperbolic reflections (e.g., Plat Pays volcanic complex, Dominica, profile 49; St. Lucia, profile 61a). On seismic reflection profiles, DADs display chaotic reflectors with large energy diffraction, which contrast with subhorizontal reflectors corresponding to the parallel-bedded sediments (e.g., Montagne Pelée, Martinique, profiles 61b and 62).
} 


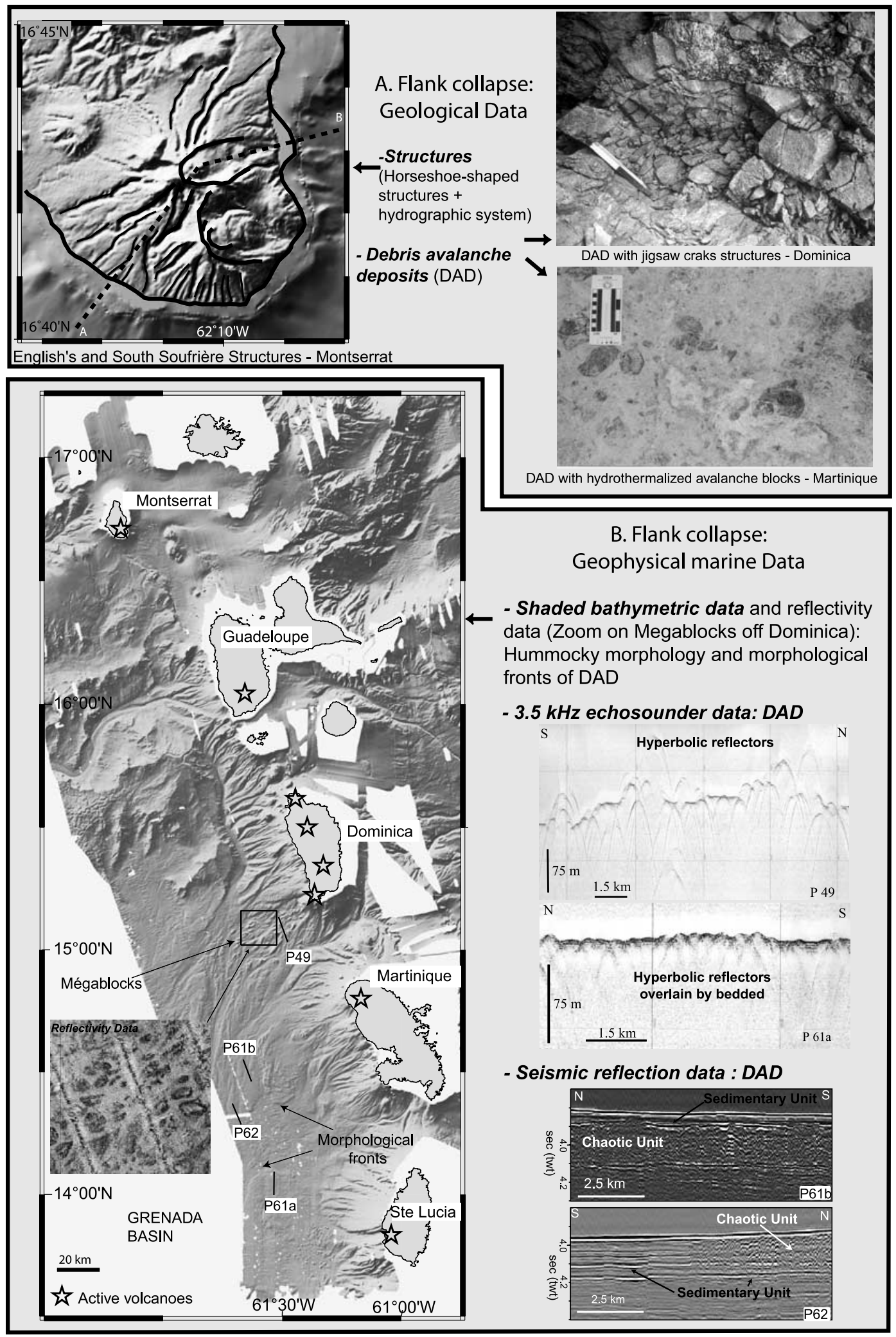

Figure 2 


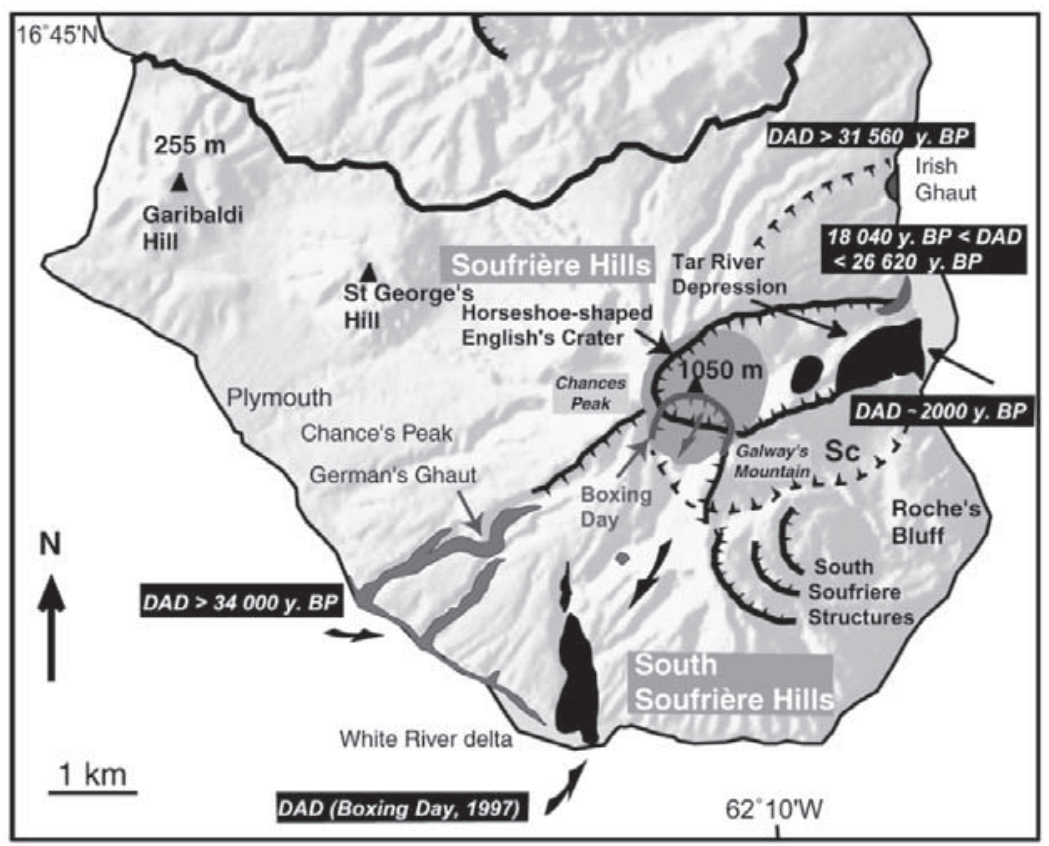

Figure 3. Shaded image of topography of the southern part of Montserrat (illumination from $\mathrm{N} 320^{\circ}$, Montserrat $10 \mathrm{~m} \mathrm{DEM}$ ) showing identified horseshoe-shaped structures and debris avalanche deposits (DAD).

[18] In addition, we use on-land geological and morphological information, digital topography and aerial photographs to identify flank collapse structures and terrestrial DADs. The rims of flank collapse structures usually show conspicuous topographic discontinuities. Patterns of the drainage systems can also be characteristic as on Montserrat, Martinique and St. Vincent. Figure 2 clearly shows hanging valleys on the southwestern flank of Soufrière Hills volcano, which indicate that their upper part has been cut by a discontinuity. Age relationships are determined by stratigraphic constraints from U-Th disequilibrium dating of lava domes and flows, as well as ${ }^{14} \mathrm{C}$ dating of paleosol horizons and pyroclastic deposits that are intersected by the flank collapse structures or constitute infilling post collapse sequences. They provide significant constraints on the chronology of the events [Komorowski et al., 2002; Le Friant et al., 2003].

\section{Islands of the Northern Part of the Arc}

\subsection{Montserrat}

\subsubsection{Soufrière Hills and South Soufrière Hills Volcanic Complexes}

[19] Soufrière Hills volcano has experienced several edifice collapse events in its past history. The most recent edifice collapse occurred on 26 December 1997 and is known as the Boxing Day event (Figure 3). It produced a debris avalanche $\left(\sim 40-50 \times 10^{6} \mathrm{~m}^{3}\right)$ which flowed down the White River Valley and stopped within $20 \mathrm{~m}$ of the coast. Flank failure was attributed to hydrothermal alteration of the southwestern flank above the fumarolic field of Galway's Soufrière as well as internal deformation and overloading associated with the actively growing lava dome [Voight et al., 2002; Young et al., 2002]. Following emplacement of the debris avalanche, sudden depressurization of the growing lava dome and the hydrothermal system resulted in a destructive laterally spreading pyroclastic density current which covered $10 \mathrm{~km}^{2}$ on the southwestern flank of the edifice. It was immediately followed by pyroclastic block-and-ash flows from the lava dome which also entered the sea and produced a tsunami $2 \mathrm{~m}$ high on the western coast of the island [Sparks et al., 2002]. Despite its small volume, this collapse caused the most widespread devastation on the small island $\left(110 \mathrm{~km}^{2}\right)$ since the onset of the eruption in 1995.

[20] Dome growth from the current decade-long eruption has essentially taken place within English's crater with a horseshoe-shaped morphology typical of a flank collapse structure (Figure 3) and interpreted as such by Wadge and Isaacs [1988]. Roobol and Smith [1998] proposed an age of $3950 \pm 70$ years B.P. for the English's Crater flank collapse based on ${ }^{14} \mathrm{C}$ dating of charcoal from a dense andesite ash flow deposit (Marker $\mathrm{G}$ ) that forms a thin veneer extending along the east coast north of Tar River valley. We observed before and at the beginning of the ongoing eruption relict outcrops of a subaerial DAD in the middle and lower part of the Tar River valley and in the cliffs of the eastern coastline [Boudon et al., 1996, 1998]. They have become more apparent as a result of the ongoing eruption. The voluminous block-and-ash flows resulting from the 12 July 2003 collapse of the active lava dome deeply eroded and further exhumed this DAD in the middle and lower part of the Tar River valley. The two charcoal ${ }^{14} \mathrm{C}$ dates of $1940 \pm 35$ years B.P. and $1990 \pm 30$ years B.P. that we obtained from this recently exhumed DAD clearly indicate that a much younger edifice collapse event occurred and was channelized in the Tar River valley. It is probably at the origin of the formation of English's Crater. No evidence of magmatic 


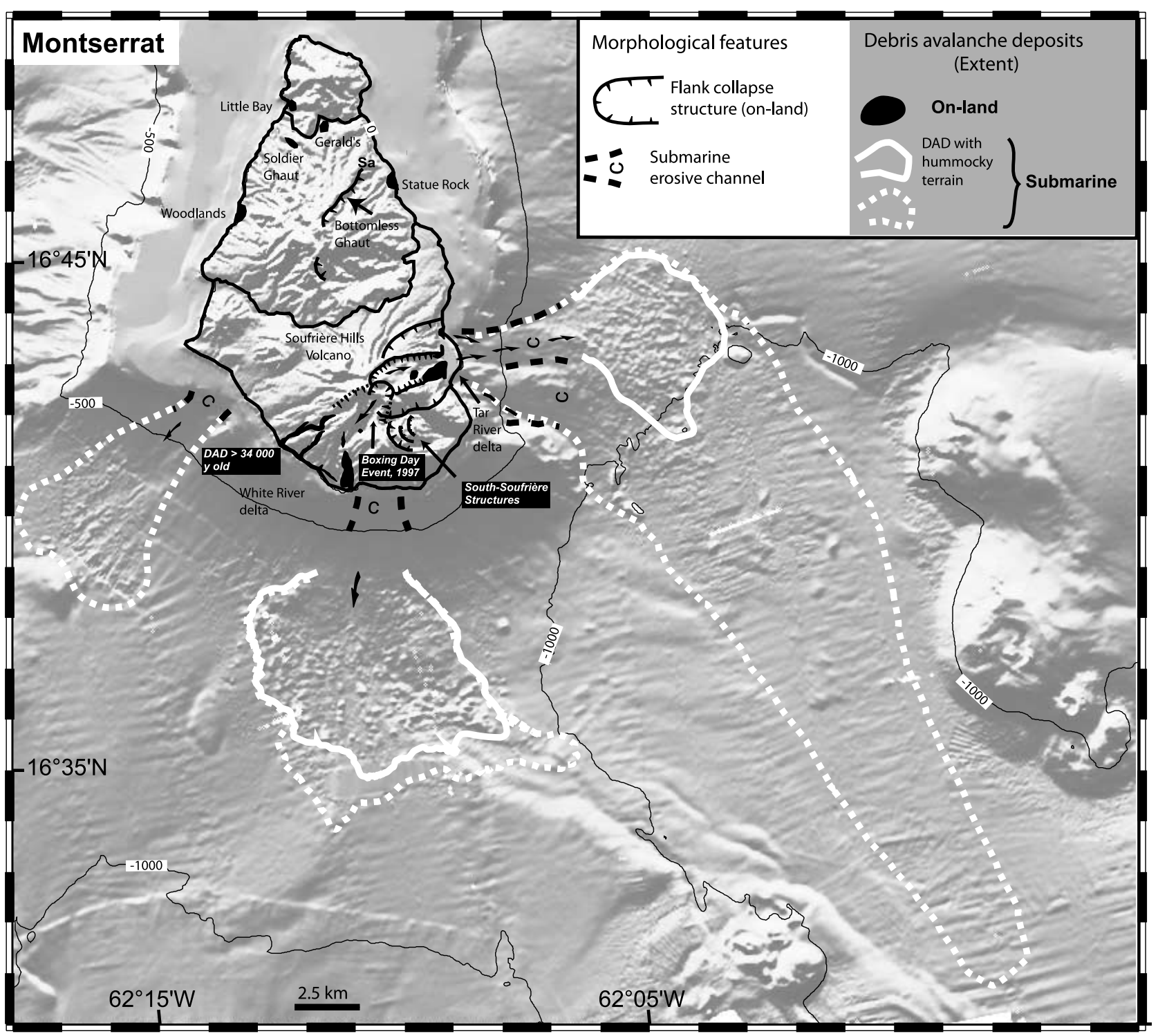

Figure 4. Shaded image of topography and bathymetry of Montserrat (illuminated from $\mathrm{N} 320^{\circ}$ ) showing debris avalanche deposits on land and offshore, main submarine troughs and flank collapse structures.

component was recognized at present in the deposits. In addition, the AGUADOMAR oceanographic survey revealed that most of the DAD material entered the sea to travel down a submarine channel extending the terrestrial amphitheater structure [Deplus et al., 2001; Le Friant et al., 2004]. The submarine extent of the deposit has the characteristic hummocky morphology (Figure 4). It covers an area of $25 \mathrm{~km}^{2}$ and its maximum volume is estimated at $\sim 0.5 \mathrm{~km}^{3}$ which is consistent with the total estimated missing volume on land in English's Crater. These recent ages are more compatible with the juvenile rough morphology of the correlative submarine DAD deposit and the absence of any sedimentary cover.

[21] Following the erosive 12 July 2003 dome collapse we have identified new outcrops of another older DAD in the upper part of the Tar River valley's northern wall as well as in the coastal cliffs from Hot River to Irish Ghaut which are capped by a thick sequence of block-and-ash flow deposits. The DAD occurs directly below a prominent reddish marker bed ("marker C" of Roobol and Smith [1998]) dated by these authors at 18,040 \pm 70 years B.P. This DAD is underlained by a thick sequence of block-andash flow deposits themselves underlain by the conspicuous yellow marker "O" of Roobol and Smith [1998] dated at $28,620 \pm 1050$ years B.P. Thus this DAD probably corresponds to deposits seen along the coastal cliffs and interpreted by Roobol and Smith [1998, p. 3393] as "lithified dense andesite block-and-ash flow deposits, which locally contain yellow and orange areas of hydrothermal alteration." These deposits were attributed to subunit II and, although undated, have an age between 28.62 and 18.04 ka based on the reconstructed stratigraphy of Roobol and Smith [1998].

[22] The ongoing eruption has denuded and scoured yet an older debris avalanche deposit several tens of meters 
thick which we identified on the southwestern flank of Soufrière Hills volcano down to the coast. Reddish orange outcrops of this DAD occur on the coastal cliffs between German's Ghaut and White River and in the main valleys of this area (Figure 3). In the upper White River they are present on each part of the paleovalley. They are overlain by a paleosol horizon and an upper thick sequence of reworked stratified units containing alternating layers of pumice-rich material with denser andesitic blocks. These fluvially reworked and colluvium deposits are overlain by a $40-$ $60 \mathrm{~m}$ thick series of block-and-ash flow deposits topped by another younger paleosol horizon. We assume that the upper block-and-ash flow deposits correspond to those dated by Roobol and Smith [1998] from about 22 to 31 ka of age. Although it is not well defined, we propose that the collapse amphitheater might be identified as a horseshoe-shaped structure open to the SW, truncating Galway's Mountain, the northwestern part of South Soufrière Hills complex and the southern part of Chance's Peak where a vertical steep straight wall might correspond to the NW portion of this structure. A sample of charcoal obtained at the base of this DAD deposit in German's Ghaut gave a ${ }^{14} \mathrm{C}$ age $>34 \mathrm{ka}$.

[23] An older debris avalanche deposit with a larger extent $\left(>200 \mathrm{~km}^{2}\right)$ and a volume on the order of a few cubic kilometers has been recognized offshore underneath the younger submarine DAD [Deplus et al., 2001; Le Friant et al., 2004]. It extends to $30 \mathrm{~km}$ from the coastline and has a less hummocky morphology than the younger deposit (Figure 4). This debris avalanche probably formed as a result of a submarine and subaerial flank collapse of the eastern flank of South Soufrière Hills volcano related to the large horseshoe-shaped structure open to the east ( $\mathrm{Sc}$ of $\mathrm{Le}$ Friant et al. [2004]). The age of this event is estimated to be between the age for the onset of eruptive activity from South Soufrière Hills volcano at $130 \mathrm{ka}$ and the emplacement of Galway's Mountain dome dated at $112 \mathrm{ka}$ [Harford et al., 2002] inside the horseshoe-shaped depression. We discovered on land near the mouth of Irish Ghaut at sea level (Figure 3) and at the base of the sea cliff very limited outcrops of a DAD. It is overlain by a series of block-andash flow deposits from Subunit II of Roobol and Smith [1998] whose base they dated between 31,560 \pm 230 years B.P. and 28,620 \pm 1050 years B.P. (marker "O"). This DAD likely corresponds to the subaerial part of the submarine DAD described before.

[24] Three submarine DADs were identified offshore to the southwest and south of Montserrat (deposit 3, deposit 4, and deposit 5 of Le Friant et al. [2004], Figure 4) although they cannot be clearly associated with an amphitheater source structure on land. Some of them could have been caused by massive failure of the submarine flank of the island and others might in part be associated with the South Soufrière Hills volcano.

[25] Finally, although east facing horseshoe-shaped structures have been recognized on the South Soufrière Hills volcano [Harford et al., 2002; Le Friant et al., 2004], they have not been clearly associated with subaerial or offshore DADs (Figure 3).

[26] The Soufrière Hills and South Soufrière Hills volcanic complexes have thus experienced at least 9 flank collapse events from their subaerial and/or submarine flanks, most of them occurring on Soufrière Hills volcano including two of them in the last 2000 years (Table 1). They are mainly directed to the eastern and southwestern flank of the volcanoes. For Soufrière Hills volcano, these two directions represents the directions of weakness on the edifice, the northern and southern flanks being buttressed by the Centre Hills in the north and the lava domes of South Soufrière Hills in the south, respectively. The abundance of hydrothermalized material inside the DADs is in agreement with the extensive hydrothermal alteration of the entire volcano and the numerous active fumarolic areas that were present on the volcano before the present eruption.

\subsubsection{Old Volcanoes of Montserrat}

[27] As for Soufrière Hills volcano, the older volcanoes of Montserrat have experienced several flank collapses in the eastern, northern and western directions (Figure 4).

[28] On Centre Hills ( 950-550 ka) three DADs were identified. On the western flank, a part of the sea cliff near Woodlands Bay is formed by DADs. To the north, other DADs outcrop on the left side of the Soldier Ghaut and also around the new Gerald's airport. Finally on the west side of Centre Hills volcano, DADs form the sea cliff, several tens of metres high, near Statue Rock. These deposits can be associated with the discontinuity $\mathrm{Sa}$ of Le Friant et al. [2004] with a SE facing scarp on the NW bank of Bottomless Ghaut that extended from the summit of Centre Hills to the coastline. This discontinuity which modifies the hydrographic system is interpreted as the remnant of a horseshoeshaped structure.

[29] On Silver Hills, the northern and older volcano of Montserrat, Harford et al. [2002] have recognized, on the western coast, DAD outcrops that form the sea cliff around Little Bay. No horseshoe-shaped structure can be associated with these deposits more than 1.2 Ma old.

[30] In summary, on Montserrat, at least 12 flank collapse events have been recognized for the different volcanic complexes (Table 1). For the most recent events, a horseshoe-shaped structure can be correlated to DADs on land and/or offshore. Older events can only be recognized either by relict DADs on land or offshore, or by on-land isolated horseshoe-shaped structures. At least, six of them occurred on the active Soufrière Hills volcano, two of which occurred in the last 2000 years.

\subsection{Guadeloupe}

\subsubsection{La Soufrière of Guadeloupe}

[31] The composite volcano of La Grande DécouverteLa Soufrière (thereafter named La Soufrière of Guadeloupe), in southern Basse-Terre, offers a remarkable record of repetitive collapses. At least 13 events have been identified over its life span in the last 140,000 years, 10 of which occurred in the last 15,000 years (Table 1) [Komorowski et al., 2002, 2005].

[32] The three oldest DADs were identified on the southwestern flank of the volcano, in the Rivière des Pères valley (Figure 5). They belong to the early phase of construction of La Grande Découverte edifice. These deposits all outcrop in the same type locality, the Danois quarry near Baillif, on the northern shore of the Rivière des Pères. They are separated by rather thick intercalated paleosol horizons and erosive conglomeratic channel deposits which indicate that a significant temporal hiatus separated them. Plinian pumice fall deposits are interstratified in between the DADs. Other 


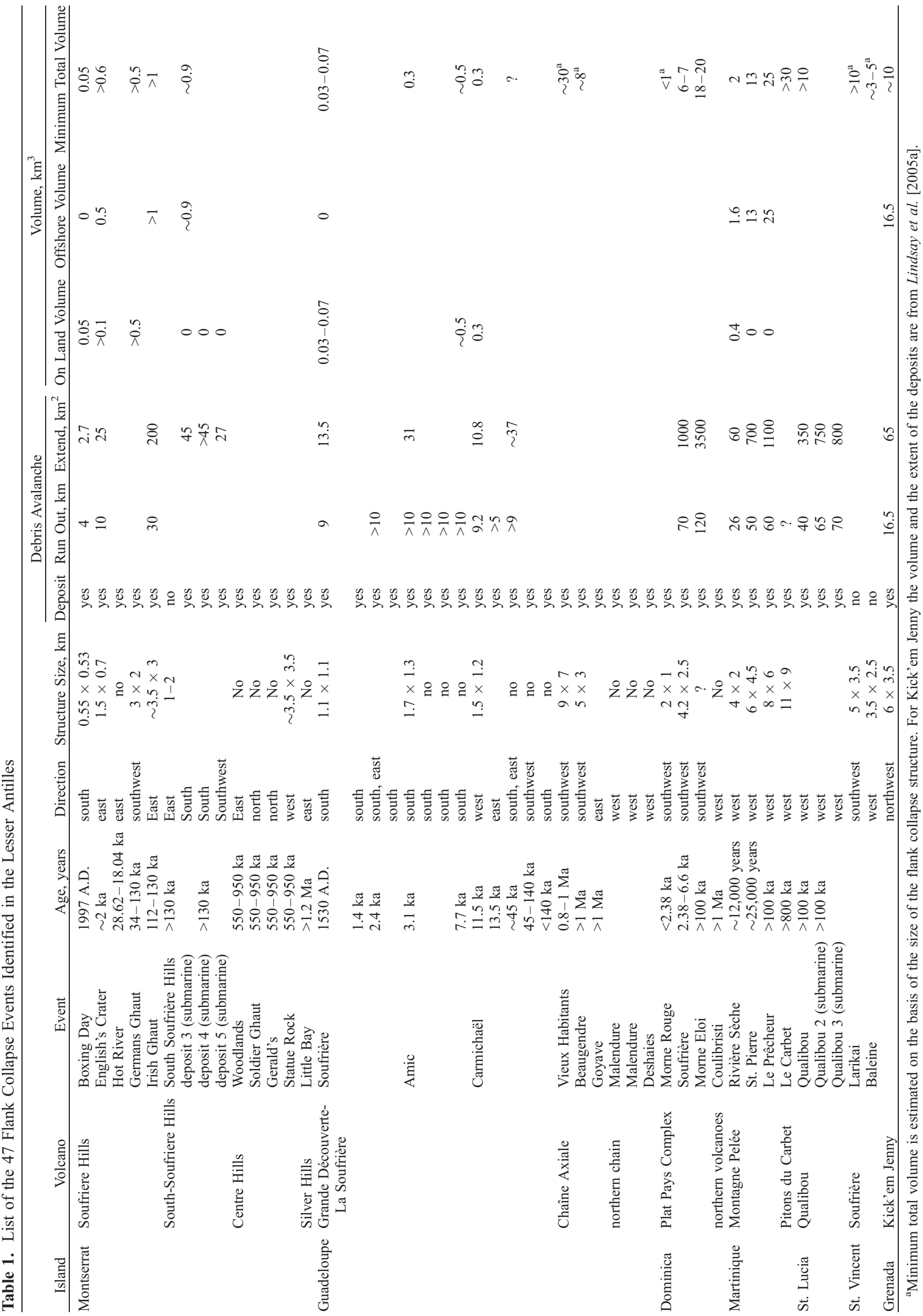




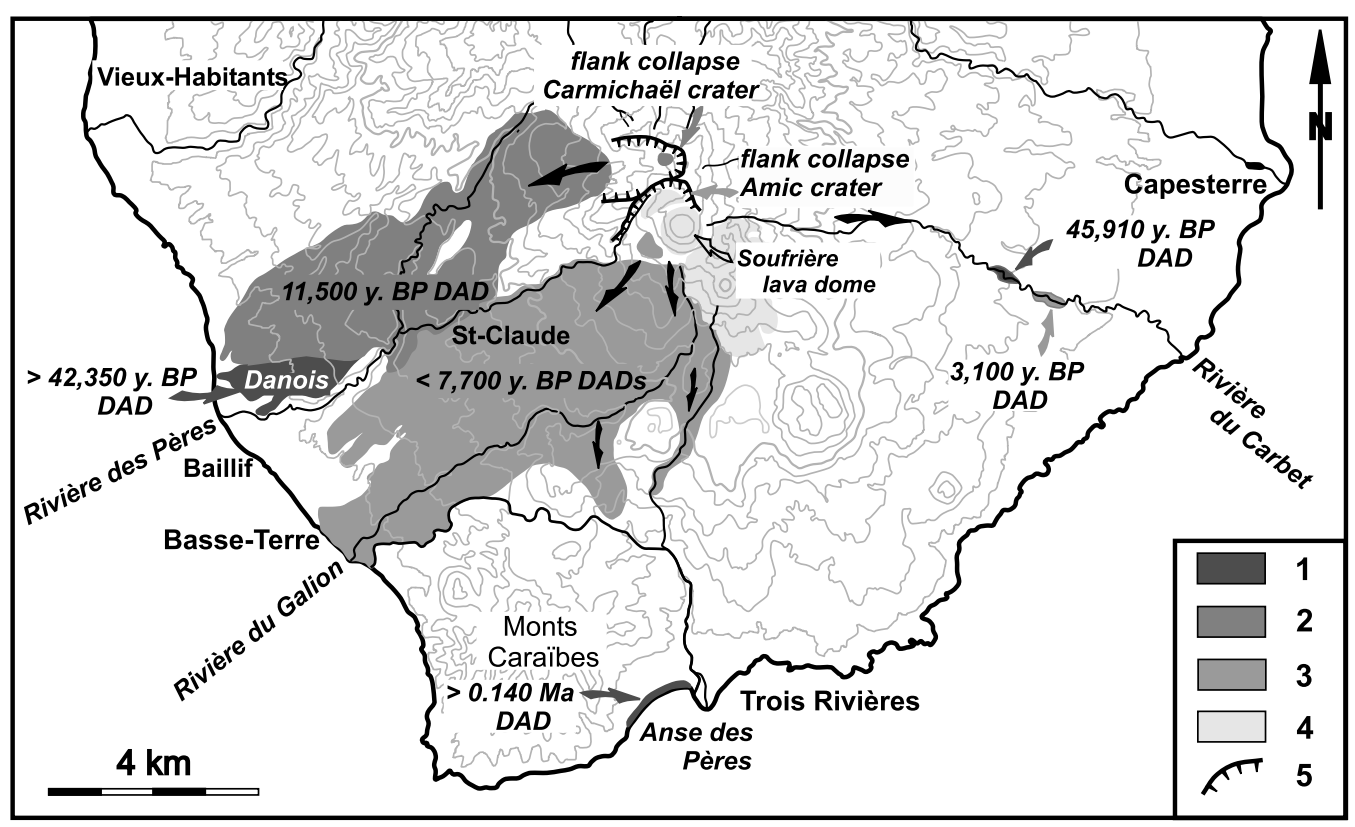

Figure 5. Map showing the debris avalanche deposits and the recent horseshoe-shaped structures of La Grande Découverte-la Soufrière volcano (Guadeloupe). Legend numbers indicate 1, old debris avalanche deposits from the first stage of construction of the volcano $(>42.35 \mathrm{ka})$; 2 , debris avalanche deposit resulting from the $11.5 \mathrm{ka}$ flank collapse event; 3, sequence of debris avalanche deposits younger than $7.7 \mathrm{ka}$; 4, Recent lava domes and scoria cones; 5, horseshoe-shaped structures.

outcrops in Trois-Rivières indicate that the oldest DAD from La Soufrière of Guadeloupe was preceded by the Anse des Pères quartz dacite pumiceous pyroclastic deposit dated at $140 \pm 14 \mathrm{ka}$ [Blanc, 1983]. The entire lower Danois quarry sequence is stratigraphically overlain by a thin pumice plinian fall unit followed by a $30-40 \mathrm{~m}$ thick coeruptive sequence of younger pumiceous pyroclastic flows belonging to the "Pintade pumice". It corresponds to a voluminous plinian caldera eruption that marked the end of the "Grande Découverte" phase of construction of La Soufrière of Guadeloupe [Boudon et al., 1989]. It is dated by ${ }^{14} \mathrm{C}$ at $42,350+1975 /-1585$ years B.P. on charcoal and at $46,000 \pm 6000$ years by U-Th disequilibrium on juvenile scoriaceous blocks (B. Villemant, personal communication, 2000). Scattered DAD outcrops were also mapped and dated at $45,910+5330 /-3180$ years B.P. to the east of the volcano summit, in the Rivière du Carbet valley (Figure 5). They are likely the stratigraphic equivalents of the deposit preceding the Pintade eruption mapped to the southwest.

[33] During the last 15,000 years, the summit part of the volcano was destroyed by a series of 10 flank collapses that have dissected the volcano into a complex edifice [Komorowski et al., 2002, 2005]. Collapses mostly affected the SW flank of the volcano and sometimes reached the sea up to $9 \mathrm{~km}$ from the summit, covering an area of at least $34 \mathrm{~km}^{2}$. A few events affected the southern and eastern flanks of the massif, reaching the Atlantic coast $10 \mathrm{~km}$ from the source. DADs are separated in time by fluvial erosion levels, paleosols, or pyroclastic units including dilute pyroclastic flow deposits. Volumes of DADs are variable but less than $0.5 \mathrm{~km}^{3}$.
[34] The 11,500-year-old event affected the western flank of the volcano, producing a debris avalanche of about $0.3 \mathrm{~km}^{3}$ that stopped at the coastline (Figure 5). The resulting horseshoe-shaped structure, the Carmichaël crater, $1.5 \times 1.2 \mathrm{~km}$ in size, is open to the west. This was a Bandaï-san-type event which did not involve any magma input [Boudon et al., 1987].

[35] At least 8 flank collapse events (of volumes between 0.02 and $0.5 \mathrm{~km}^{3}$ ) occurred afterward, during the last 7700 years. At least 2 and perhaps up to 5 of these events are associated with explosive magmatic eruptions and devastating laterally directed blasts. The most complete stratigraphic section with a total thickness of about $100 \mathrm{~m}$ that starts with the basal voluminous $7.7 \mathrm{ka}$ event can be seen in the Rivière du Galion on the SW flank of the volcano (Figure 5). Within about $5 \mathrm{~km}$ from the vent, small volume avalanches $\left(0.02-0.05 \mathrm{~km}^{3}\right)$ have been mostly channelled in the main river drainages (e.g., Galion River) to reach up to $50-60 \mathrm{~m}$ in thickness for individual ponded units. Larger volume avalanches $\left(0.05-0.5 \mathrm{~km}^{3}\right)$ have overflowed the paleoriver drainages and impacted a much wider area. These nonchanneled debris avalanche deposits can reach a thickness of 5-10 m. Deposits are almost entirely composed of very hydrothermally altered products. The capital city of Guadeloupe, Basse-Terre, and the St. Claude residential area were built on a sequence of several DADs, tens to a hundred meters thick.

[36] One of the most significant collapses of this series occurred some 3100 years ago [Boudon et al., 1984]. Avalanching of the southwestern flank of the volcano was immediately followed by a violent laterally directed blast which, from the extent of its deposits, presumably devas- 
tated about $100 \mathrm{~km}^{2}$ south of the summit. The Amic amphitheater crater, $1.7 \times 1.3 \mathrm{~km}$ in size, was thereby formed. The event was comparable to the May 1980 eruption of Mount St. Helens and probably resulted from the injection of a lava cryptodome within the southern flank of the volcano [Boudon et al., 1984]. The presently active part of the volcano, La Soufrière, developed inside the Amic crater.

[37] The last documented magmatic activity of La Soufrière of Guadeloupe led to the emplacement of La Soufrière lava dome (Figure 5) in circa 1530 A.D. (G. Boudon, manuscript in preparation, 2007). The 1530 A.D. eruption was preceded by a small flank collapse which led to emplacement of a debris avalanche that reached the Caribbean Sea in the Basse-Terre area, south of the volcano. The eruption was followed by subplinian explosive activity (J. C. Komorowski, manuscript in preparation, 2007) and ended with extrusion of the lava dome within the avalanche crater. It is suggested that the flank collapse event was triggered by the magmatic eruption in its early phase.

[38] Although a part of most of the debris avalanches flowed into the sea, no deposits were recognized offshore during the AGUADOMAR and the CARAVAL cruises. Several factors have likely contributed to this absence of a submarine record. Firstly, the bathymetry west of BasseTerre island is characterized by very steep submarine flanks and a very large funnel shape system of pronounced submarine canyons (Figure 2). Several deep and major valleys on land feed into this submarine system and thus likely contributed to the transport of debris avalanche material, primary or reworked, to great depths and distances in the back-arc Grenada Basin. Second, all DADs of the last 100,000 years are of small volume $\left(<0.5 \mathrm{~km}^{3}\right)$ and have traveled $8-10 \mathrm{~km}$ on land leading to deposits up to tens of meters in thickness which likely reduced the volume of material reaching the sea. Thirdly, La Soufrière of Guadeloupe is characterized by extensively hydrothermally altered material which forms less cohesive debris avalanche blocks that will produce over distances $>10 \mathrm{~km}$ an essentially matrix-rich deposit easily eroded, removed, and redeposited by marine processes far from the coast into the deep basin. 4.2.2. Volcanoes of the "Chaîne Axiale," the Northern Chain, and the Basal Complex

[39] Several volcanoes of the Chaîne Axiale, of the Northern Chain, and of northernmost Basal Complex of Basse-Terre island have also experienced flank collapses (Figure 6).

[40] The Sans-Toucher volcano partially fills a large horseshoe-shaped structure, $9 \times 7 \mathrm{~km}$ in size, open to the south and the Caribbean Sea and named the Vieux-Habitants structure. DADs crop out at the mouth of the structure and in coastal cliffs to the W-SW. They are covered by thick and extensive pumiceous pyroclastic flow deposits. The age of this event is now well constrained between $659 \pm 11$ and $629 \pm 13 \mathrm{ka}$ on the basis of new K-Ar dates obtained on lava flows outside and inside the structure [Samper et al., 2007]. We interpret the Beaugendre horseshoe-shaped depression, located north of the Vieux-Habitants structure, as an older $(>750 \mathrm{Ma})$ flank collapse structure $(5 \times 3 \mathrm{~km}$ in size $)$ also open to the Caribbean Sea. DADs have been identified at the mouth of the structure.
[41] We have roughly estimated a collapse volume of $\sim 30 \mathrm{~km}^{3}$ for the Vieux-Habitants event and of $\sim 8 \mathrm{~km}^{3}$ for the Beaugendre event. It is likely that the main part of the debris avalanches flowed into the Caribbean Sea. However, the presence west of the island of very steep submarine flanks and of a very large funnel shape system of pronounced submarine canyons (Figure 2) contributed to reworking the primary deposits of all recent DADs and to transporting them into the deep Grenada Basin.

[42] Relicts of several DADs have been mapped along the western coast of the northern part of Basse-Terre. They originated from the oldest volcanoes of the island, $>1 \mathrm{Ma}$ old, and thus cannot be related to horseshoe-shaped structures. However these deposits attest that these old volcanoes have also experienced flank collapses. At least two groups of outcrops have been recognized. The first group, north of the village of Bouillante, can be linked to two distinct events with two DADs being separated by a sequence of ash-and-pumice fall deposits, several meters thick. The second group is located north of the village of Pointe Noire, with outcrops along the coastline for about $3 \mathrm{~km}$. The deposits are chaotic breccias mixed with highly hydrothermally altered material. Similar highly hydrothermally altered chaotic clastic deposits have been found in the area of Morne Mazeau, east of Deshaies. They belong to the Northern Chain volcanic complex.

[43] The eastern coastal road (Atlantic Ocean side) between Capesterre and Goyave cuts repeatedly through a thick distal volcaniclastic sequence corresponding to erosion and mass wasting of the older volcanic (1.25-0.45 Ma) complexes of the Chaîne Axiale (e.g. Matéliane, Morne Moustique, Pitons de Bouillante). These deposits constitute a thick detrital clastic apron dissected by erosion to form a series of SE-NW oriented elongated hills and valleys. A thick $(10-15 \mathrm{~m})$ unit consisting either of subrounded to subangular blocks of lava and/or brecciated hydrothermally altered material might correspond in part to very distal relict outcrops of DADs related to the edifice collapses of the Chaine Axiale volcanoes toward the $\mathrm{E}$ and $\mathrm{NE}$.

\section{Islands of the Southern Part of the Arc}

[44] In the southern part of the arc (Dominica to Grenada), flank collapse events are less numerous on each volcano but involve significant volumes of material (several $\mathrm{km}^{3}$ to tens of $\mathrm{km}^{3}$ ).

\subsection{Dominica}

\subsubsection{Plat Pays Volcanic Complex}

[45] Marine and terrestrial data from Le Friant et al. [2002] support a scenario for the evolution of the Plat Pays volcanic complex, located in the southern part of Dominica that was significantly controlled by a succession of constructional phases with dominant lava domes and associated block-and-ash flow deposits, and at least three flank collapse events. On the basis of marine geophysical data gathered during the AGUADOMAR cruise, Le Friant et al. [2002] have shown that voluminous DADs extend offshore of the southwestern part of Dominica. Extensive field work on land was undertaken to understand the relationship between submarine DADs and the evolution of the Plat Pays volcanic complex. Lindsay et al. [2003] do 


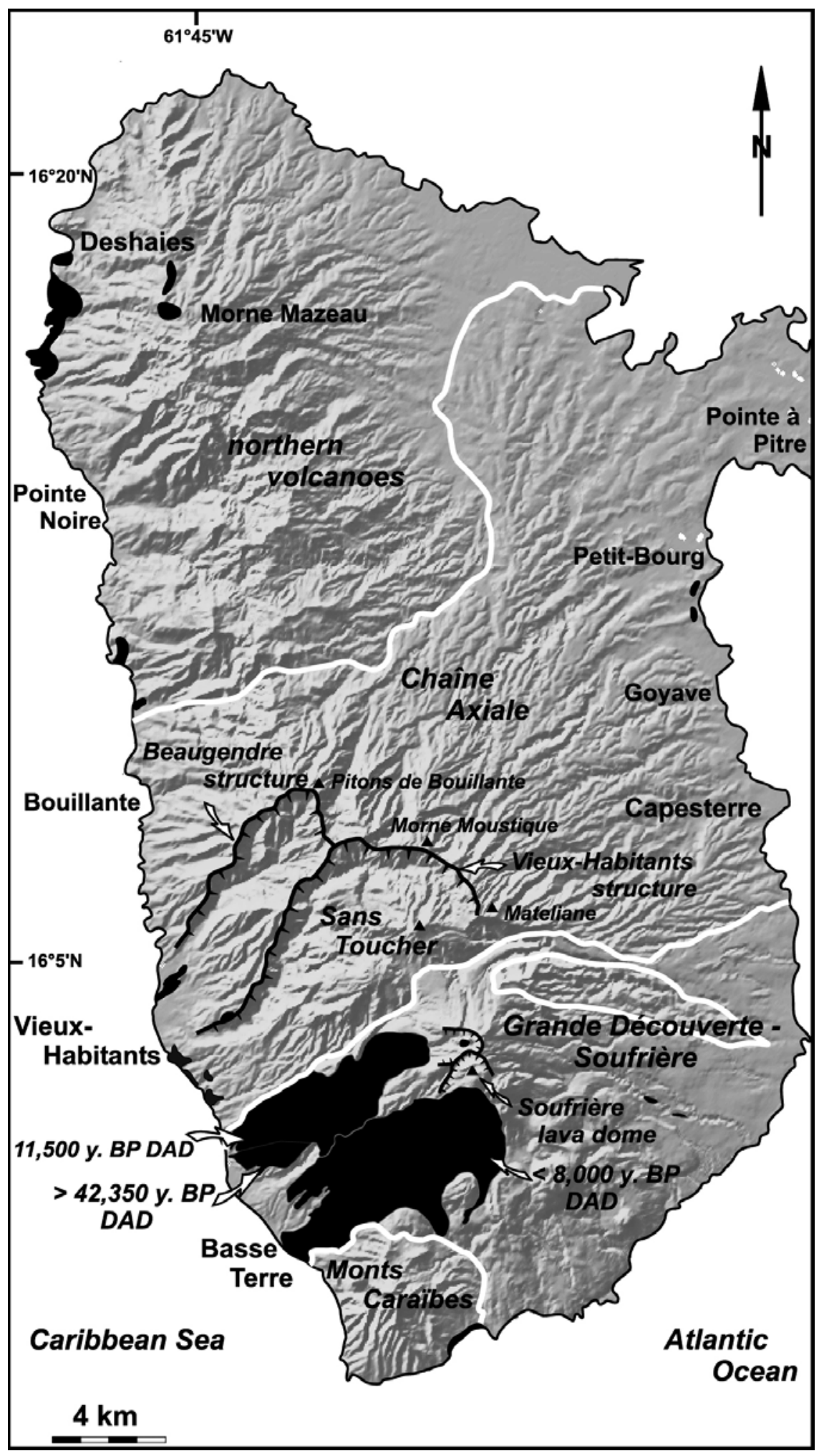

Figure 6. Shaded image of topography of the island of Basse-Terre in Guadeloupe, illuminated from $\mathrm{N} 320^{\circ}$, showing the main debris avalanche deposits (black solid fill) and associated horseshoe-shaped structures from the different periods of activity.

not agree with this interpretation and presented an alternative model for the geological evolution of the Plat Pays volcanic complex, on the basis of geological, petrologic and geochronological data. They proposed that the volcano experienced a major caldera collapse triggered by a voluminous pyroclastic eruption dated at about $39 \mathrm{ka}$ and that this event was followed by the extrusion of 12 lava domes within and outside the caldera. 


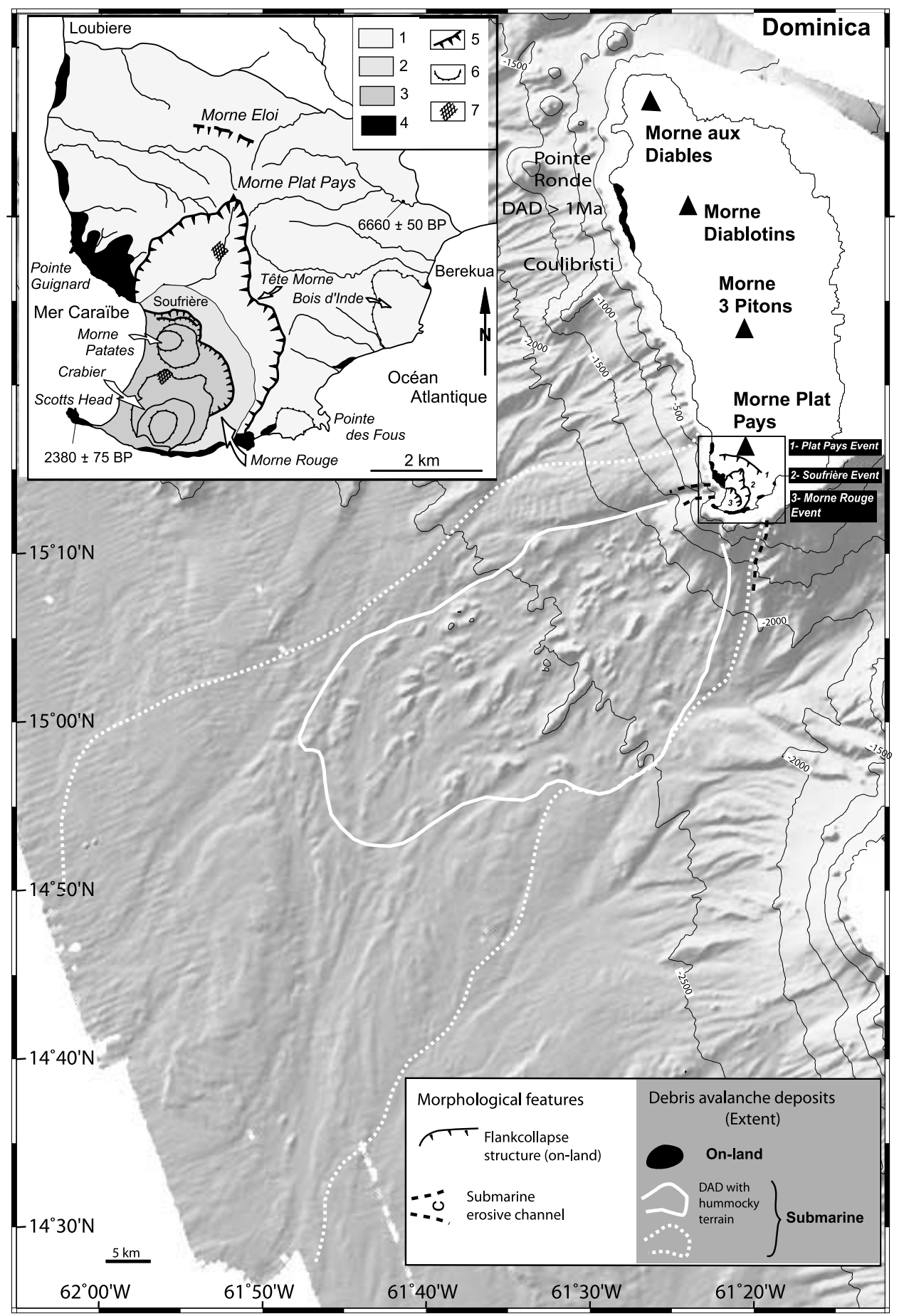

Figure 7. Shaded image of bathymetry west of Dominica illuminated from $\mathrm{N} 320^{\circ}$, showing the different debris avalanche deposits (areas with and without megablocks). Debris avalanche deposits on land are also reported. Inset shows simplified geological map of Plat Pays volcanic complex, Dominica resulting from this study. Legend numbers indicate 1, Plat Pays volcanic deposits; 2, Morne Rouge volcanic products; 3 , recent volcanism; 4 , debris avalanche deposits; 5 , flank collapse structures, 6 , lava domes, 7, fumarolic fields.

[46] Several lines of evidence favour the first hypothesis with successive flank collapse events occurring during the evolution of the volcanic complex.

[47] 1. Offshore DADs cover an area of $3500 \mathrm{~km}^{2}$ on the southwestern submarine flank of Dominica off Plat Pays volcanic complex. A characteristic hummocky morphology is typical of the proximal areas $\left(1100 \mathrm{~km}^{2}\right)$ between the isobaths 1400 and $2700 \mathrm{~m}$ (Figure 7). It consists of very numerous megablocks (up to $2.8 \mathrm{~km}$ in length and $240 \mathrm{~m}$ in height), some of which are aligned in the NE-SW direction 
in agreement with the most plausible volcanic source being located in southern Dominica.

[48] 2. At least two well-identified horseshoe-shaped structures are recognized (Figure 7). They are open to the west to the Caribbean Sea. The largest one, the Soufriere depression, is $4.2 \times 2.5 \mathrm{~km}$ in size, with rims up to $900 \mathrm{~m}$ high. The second one, smaller and more recent, is located inside the preceding structure.

[49] 3. Abundant on-land DADs are present on the coastal area. Some of these deposits are located on the southern coast at the mouth of the Soufriere depression. They are constituted of fractured lava megablocks with characteristic jigsaw fit structures (Figure 2). Scotts Head hill is a megablock $(500 \times 300 \mathrm{~m}, 60 \mathrm{~m}$ high $)$ made of massive lava with a characteristic clastic fabric. It is consistent with the size of the abundant submarine megablocks identified offshore. Abundant DADs are also present along the western coast, north of Soufrière structure. They are made of a series of megablocks constituted of fractured massive lavas, hydrothermal products and scarce pyroclastic deposits. They are located in the continuation of the northern part of the offshore DAD (Figure 7). Le Friant et al. [2002] associated this DAD with the remnant of an old structure (Morne Eloi), covered by the pyroclastic products of a new edifice that infilled the structure and flowed over its rims.

[50] We can consider that three flank collapse events occurred on the Plat Pays volcanic complex. The first (Morne Eloi event) is the largest and occurred after the construction of the first cone. On the basis of the extent of the DAD, its thickness and the sedimentary cover, Le Friant et al. [2002] proposed a collapse volume of $18-20 \mathrm{~km}^{3}$ and a minimum age of $100 \mathrm{ka}$. The second one (Soufriere event) was produced after construction of the second cone inside the first structure. Concerning the submarine extent of the structure's rims, the concave shape of the coast suggests that part of the submarine flank (100 to $200 \mathrm{~m}$ high) was probably associated with the collapse. The missing volume is estimated to be $6-7 \mathrm{~km}^{3}$. On the basis of ${ }^{14} \mathrm{C}$ radiocarbon dates for subaerial deposits on top of DAD hummocks, we propose that the youngest edifice collapse event occurred between $6600 \pm 50$ and $2380 \pm 75$ years B.P. A new volcanic edifice constructed inside the structure was partly destroyed by a third flank collapse event whose horseshoeshaped structure is well preserved. Its volume is estimated to be $<1 \mathrm{~km}^{3}$. The main part of the debris avalanche probably flowed offshore, but these deposits cannot be clearly distinguished from the preceding ones in the absence of intercalated or overlying sediments. The lava dome of Morne Crabier and the recent lava dome of Morne Patates (with ${ }^{14} \mathrm{C}$ dates obtained on the associated block-and-ash flow deposits of $685 \pm 55$ [Lindsay et al., 2003] and $450 \pm$ 90 years B.P. [Roobol et al., 1983]) are located inside this last structure.

\subsubsection{Old Volcanoes of Dominica}

[51] In the northern part of Dominica, we have also identified old ( $>1 \mathrm{Ma}$ ) DADs (Figure 7). They cover a large area between Coulibristi and Pointe Ronde and can be clearly observed along the western coast and in outcrops of the main western road. They are characterized by the abundance of blocks, meters to tens of meters in size, of hydrothermally altered rocks suggesting that an active hydrothermal system had developed before the presumed collapses. No DADs were identified offshore. As a result of the extensive hydrothermal alteration of the products and their old age, it is probable that potential submarine DADs did not survive erosion and/or were covered by a thick sediment blanket that prevented their detection by the usual marine geophysical profiling techniques.

\subsection{Martinique}

\subsubsection{Montagne Pelée}

[52] As for volcanoes of southern Dominica, the evolution of Montagne Pelée volcano has been marked by three major flank collapses (Figures 8 and 9) which destroyed systematically the western flank of the volcano [Le Friant et al., 2003]. Their occurrence significantly modified the structure and the magmatic activity of the volcano and is therefore used to subdivide the geological evolution of the volcano into three main stages.

[53] The first event marks the end of the constructional first stage $(\sim 0.1 \mathrm{Ma})$. Only the northern rim of the resulting horseshoe-shaped structure is preserved (Figure 9). It extends from the coastline to the summit area and forms a cliff up to $500 \mathrm{~m}$ high on the right banks of Le Prêcheur and Samperre valleys. The southern rim is masked or destroyed by more recent flank collapses. Morne Julien, a $386 \mathrm{~m}$ high hill south of Le Prêcheur, composed of massive lavas dislocated by a pervasive jigsaw crack system, is interpreted as a series of juxtaposed megablocks transported by the debris avalanche. It is the only evidence of a subaerial deposit. The main part of the debris avalanche flowed into the Grenada Basin and its deposit extends up to $60 \mathrm{~km}$ from the coastline and covers an area of $1100 \mathrm{~km}^{2}$ (Figure 8). The size of the structure is estimated to be $8 \times 6 \mathrm{~km}$ with a collapse volume of $25 \mathrm{~km}^{3}$.

[54] The second event occurred following the construction of a new and voluminous edifice inside the first horseshoe-shaped structure. The debris avalanche flowed into the Caribbean Sea and its deposit covers a part of the first debris avalanche deposit (Figure 8). It extends up to $50 \mathrm{~km}$ from the coastline and covers an area of $700 \mathrm{~km}^{2}$ displaying a distinctive topographic front, 10 to $35 \mathrm{~m}$ high. It is located at the mouth of a trough, $13 \mathrm{~km}$ long and $4 \mathrm{~km}$ wide, on the submarine flank of the volcano, well-defined in the topography and interpreted as resulting from erosion by emplacement of the debris avalanche. The rims of the horseshoe-shaped structure on land are in perfect alignment with the rims of the trough. The structure $(6.5 \times 4 \mathrm{~km})$ cuts the western flank of the cone. Its northern and southern rims are well defined in the topography, but its upper part disappears under the more recent volcanic deposits. No subaerial DADs are recognized. The concave shape of the coast at the mouth of the structure attests that a small part of the submarine flank (less than $200 \mathrm{~m}$ ) is associated with the flank collapse. The collapse volume is estimated to be $13 \mathrm{~km}^{3}$. On the basis of ${ }^{14} \mathrm{C}$ dates on charcoal included inside pyroclastic deposits filling the structure and U-Th disequilibrium dates obtained on lava domes cut by the rim of the structure, the flank collapse event occurred about 25,000 years ago. Magmas erupted before this flank collapse were acid andesites to dacites. Magmas erupted after the collapses are of basaltic andesite composition. This change in composition is compatible with tapping of more basic magma enhanced by a decrease of the load on the 


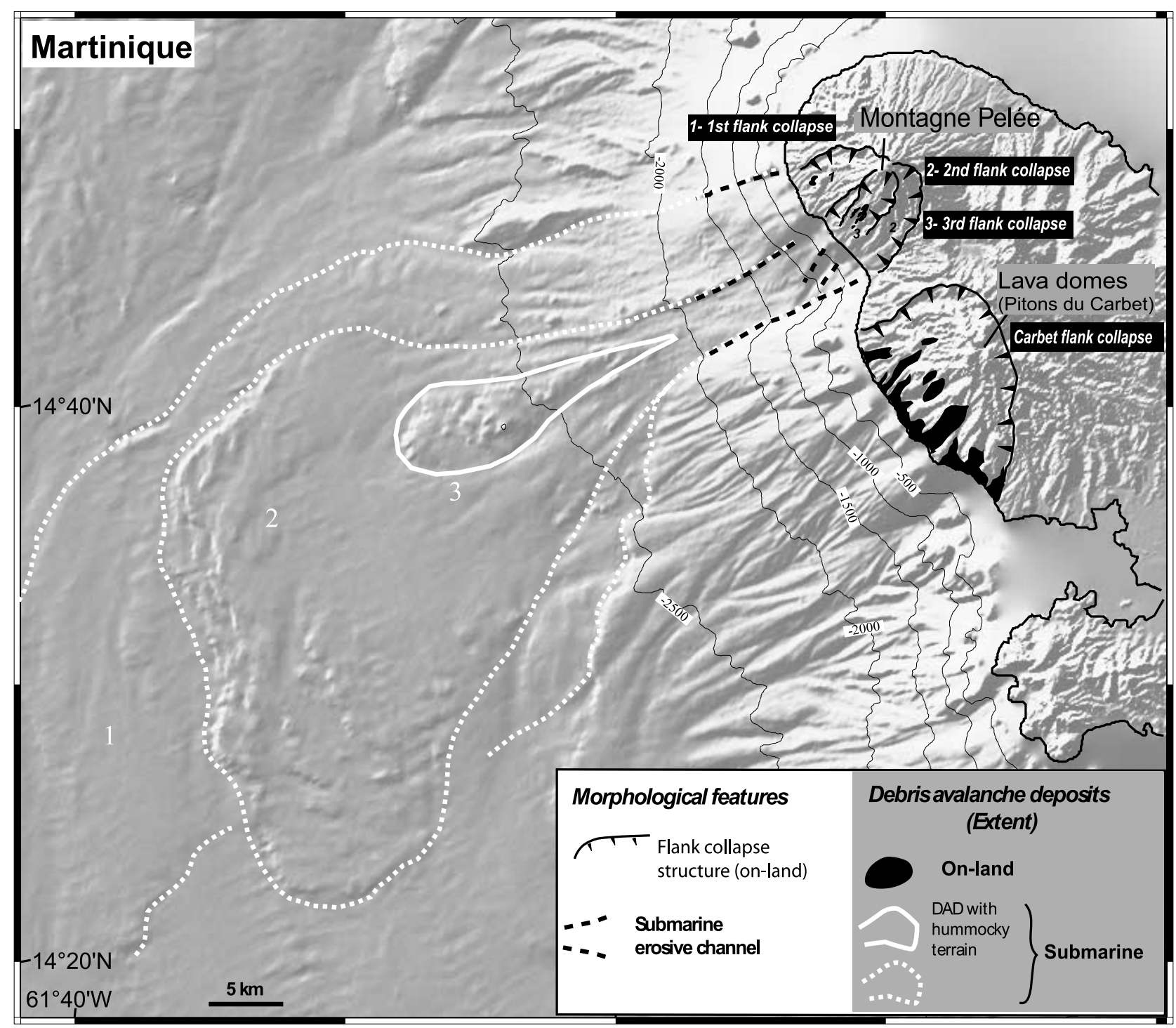

Figure 8. Shaded image of topography and bathymetry of Martinique illuminated from $\mathrm{N} 320^{\circ}$. Reported are offshore, the three debris avalanches; on land, the horseshoe-shaped structures and the debris avalanche deposits from Montagne Pelée and Pitons du Carbet volcanoes.

magma chamber as a consequence of the flank collapse as modelled by Pinel and Jaupart [2000]. Ascent of denser more basic magmas was thus promoted for several thousand years. After the new cone reached a critical volume, more superficial acidic magmas were erupted.

[55] The new cone was destroyed again by a third flank collapse event with a smaller volume than the preceding ones (Figure 9). It forms a horseshoe-shaped structure, $4 \times$ $1.5 \mathrm{~km}$ with cliffs several hundred meters high, inside the second structure. Associated DADs were identified on land and offshore. The deposit covers an area of $60 \mathrm{~km}^{2}$ on the submarine flank of the volcano, has a lobate shape and presents a characteristic hummocky morphology with megablocks $100-500 \mathrm{~m}$ in size (Figure 8). On land, a series of megablocks inside and at the mouth of the structure clearly stand out in the topography. The total collapse volume is estimated at $2 \mathrm{~km}^{3}$. The age proposed by
Le Friant et al. [2003] from U-Th disequilibrium dating of lava domes emplaced before and after the collapse is around 9000 years. A more recent tephrochronologic study (L. Duchoiselle, unpublished data, 2003) of a piston core from the CARAVAL cruise northwest of Montagne Pelée, has identified a tephra layer associated with this flank collapse event which yields a more precise $\delta^{18} \mathrm{O}$ age about 12,000 years. Continuous magmatic activity has produced a new cone that almost entirely fills the last horseshoe-shaped structure.

\subsubsection{Pitons du Carbet}

[56] Pitons du Carbet volcano, south of Montagne Pelée, has also experienced a major sector collapse, probably the largest of all Lesser Antilles volcanoes [Boudon et al., 1992]. The paleoedifice was built on the western flank of Morne Jacob, a 3-5 Ma old volcano. In the collapse, a large fraction of this edifice was destroyed. The horseshoe-shaped 


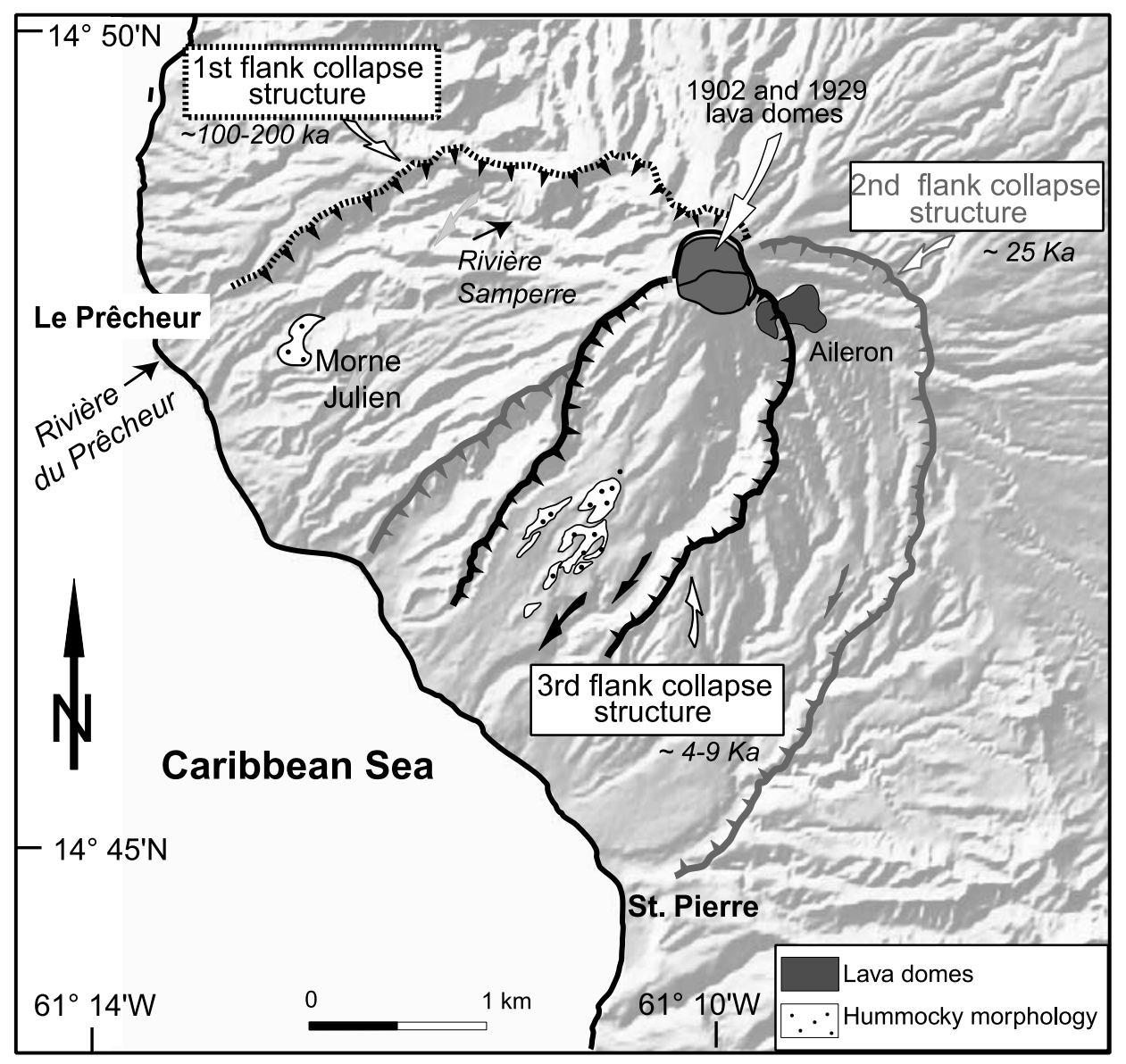

Figure 9. Shaded image of topography of the southwestern part of Montagne Pelée volcano (Martinique), illuminated from $\mathrm{N} 320^{\circ}$, showing the three horseshoe-shaped structures and the on-land debris avalanche deposits.

structure, $11 \times 9 \mathrm{~km}$ in size, is again open to the west (Figure 10). Only the northern and parts of the northeastern rims are well preserved, the southeastern rim being partly covered by more recent products. The main part of the debris avalanche flowed to the west in the Caribbean Sea toward the Grenada Basin but spectacular outcrops occur in sea cliffs between Le Carbet and Fort-de-France (Figure 10), in some cases more than a hundred meters high. These deposits are primarily composed of a mixture of avalanche blocks that consist of dominantly matrix facies and hydrothermally products. Very few lava blocks were identified in the deposits. As it is often the case for older events, its age is not well constrained. The K-Ar ages cited by Westercamp et al. [1989] for magmatic activity that predates and postdates the collapse indicate an age older than $1 \mathrm{Ma}$, but new K-Ar dates obtained recently (A. Samper, preprint, 2007) bracket the age of the flank collapse between $770 \pm 11$ and $341 \pm 5 \mathrm{ka}$. Offshore deposits were not identified in the AGUADOMAR or CARAVAL cruise profiles.

\subsection{St. Lucia}

[57] The origin of the Qualibou caldera has been the subject of discussion. Some authors interpreted it as a collapse caldera associated with eruption of voluminous ash-and-pumice flows [Tomblin, 1965; Wohletz et al., 1986]. Others considered it as a collapse structure. Roobol et al.
[1983] proposed that the caldera could be identified morphologically by a horseshoe shape open to the Caribbean Sea. Wright et al. [1984] considered, on the basis of the extent of the ash-and-pumice flows that they cannot come from this caldera. More recently Mattioli et al. [1995] showed, on the basis of bathymetric data, that the Qualibou caldera is a horseshoe-shaped structure prolonged offshore by a trough several hundred meters deep between 0 and $1500 \mathrm{~m}$ below sea level (bsl). No DADs were identified on land or offshore.

[58] A detailed geological study of the structure and marine data of the AGUADOMAR cruise support a reinterpretation of the origin of the Qualibou structure [Le Friant, 2001]. On the basis of criteria for identification of the DADs offshore (bathymetry and backscatter data, 3.5 acoustic and seismic reflection profiles; see section 3 and Figure 2), we have identified three areas of DADs (Figure 11). The first one is a hummocky area with an extent of $350 \mathrm{~km}^{2}$. Most of the megablocks, 20 to $110 \mathrm{~m}$ high, are deposited on the flat area of the Grenada Basin. The second and the third areas 750 and $800 \mathrm{~km}^{2}$, respectively, have a geophysical signature (hyperbolic reflections and chaotic reflectors) characteristic of DADs. The second deposit has a very well defined morphological front, 20 to $30 \mathrm{~m}$ high. The sedimentary layers $(\sim 10 \mathrm{~m}$ thick for the hummocky deposit, and several tens of meters for the other 


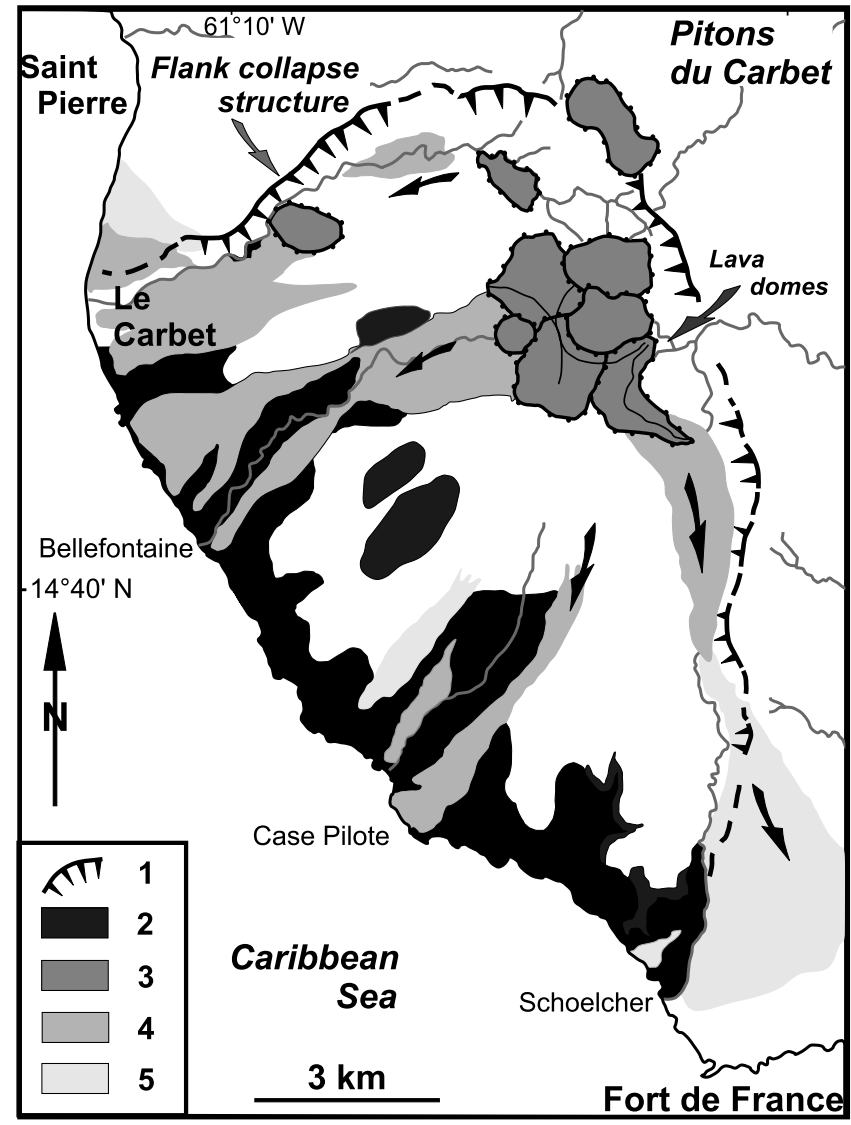

Figure 10. Simplified geological map of the flank collapse structure of Pitons du Carbet, Martinique. Flank collapse event: 1, horseshoe-shaped structure; 2, debris avalanche deposits generated by the flank collapse. Volcanism post flank collapse: 3, lava domes; 4, block-and-ash flow deposits associated with the lava domes; 5, ash-and-pumice flow deposits.

deposits) which partly covered all of these DADs provide evidence of their old age. These deposits are located at the mouth of a trough which extends from the coastline to the isobath $2770 \mathrm{~m}$. This trough, $6 \mathrm{~km}$ long and 4.5 to $6 \mathrm{~km}$ wide, is similar to the trough observed on the submarine flank of Montagne Pelée.

[59] On land, the Qualibou caldera (Figure 12) has a horseshoe shape, $5 \times 6 \mathrm{~km}$ in size, is open to the Caribbean Sea, and forms regular northern and southern rims, several hundred meters high. The eastern rim is more complex, because of the presence of several poststructure gravity slides. We have identified several deposits that we interpret as DADs inside the structure. Some of them form hills a hundred meters or more high, considered to be megablocks associated with the debris avalanches. Most consist of lavas with characteristic jigsaw crack structures and were previously interpreted as old lava domes and lava flows. All of these lavas are of basaltic or andesitic composition similar to the composition of the lavas that form the rims of the structure. They contrast with the more recent lava domes and their associated pyroclastic flows, of dacitic composition, located inside the Qualibou structure.
[60] On the basis of (1) the presence of the large extent of offshore DADs at the mouth of a trough on the submarine flank of the island; (2) the alignment of the rims of the trough with the rims of the Qualibou structure open to the sea; and (3) the identification of subaerial DADs inside the structure, we propose that the Qualibou structure partially originated by at least one flank collapse. The hummocky deposit is the result of the last flank collapse. It is covered by sedimentary layers whose thickness suggests that this event occurred several tens of thousand years ago. The other older deposits, could be associated with older flank collapses of the volcano or more probably, as proposed by Le Friant [2001], with failure of the submarine flank of the island.

\subsection{St. Vincent}

[61] No debris avalanche deposits were identified on the island of St.Vincent. However, on the active volcano of Soufriere, two horseshoe-shaped structures that we interpret as resulting of flank collapse events can be identified (Figure 13). The first and older one is the Baleine structure which cuts a preexisting primitive volcanic edifice. Open to the west toward the Caribbean Sea, only its northern and eastern rims are well preserved. They extend from the coastline to the summit area, forming a cliff up to $300 \mathrm{~m}$, on the right bank of the Baleine River. The northern rim is clearly defined by the hydrographic system (Figure 13). The valleys north of the rim generally display a northern direction whereas south of the rim, inside the structure, they are mainly directed to the west. The construction of a new cone named "Somma" inside the structure, but offset to the southwest, has masked its southern rim. In regard to the geometry of the preserved rims of the structure, the southern rim may be located in the direction of the Larikai Bay. Its size can be estimated to $5 \times 3.5 \mathrm{~km}$ and the missing volume is $>10 \mathrm{~km}^{3}$. The age of this structure is unknown, but in relation to the voluminous "Somma" cone located in the structure as well as the extent of the deposits (mainly lava flows) on land beyond the presumed old coastline, we suggest that the structure is several hundred thousand years old. The deposits of this voluminous cone cover the older debris avalanche deposits. The "Somma" cone located in the Baleine structure is cut by a second horseshoe-shaped structure, $2.5 \times 3.5 \mathrm{~km}$ in size, open to the southwest which cuts in its northwest part the older structure of Baleine. Its northwest rim is well preserved with cliffs up to $250 \mathrm{~m}$ whereas its southeastern rim disappears under the products of the more recent cone of Soufrière located inside the structure. The young age of Soufriere's new cone means that this horseshoe-shaped structure is probably not older than several thousand years. The collapse volume is on the order of $3-5 \mathrm{~km}^{3}$.

\subsection{Kick'em Jenny, Grenada}

[62] On the basis of the first bathymetric coverage in the vicinity of the submarine Kick'em Jenny volcano obtained during the SEACARIB cruise [Bouysse et al., 1988], Boudon et al. [1999] and Le Friant [2001] proposed that the small Kick'em Jenny cone is located inside a welldefined horseshoe-shaped structure, $6 \times 3.5 \mathrm{~km}$ in size, open to the northwest (Figure 14). It could be interpreted as the result of the collapse of the steep western sector toward 


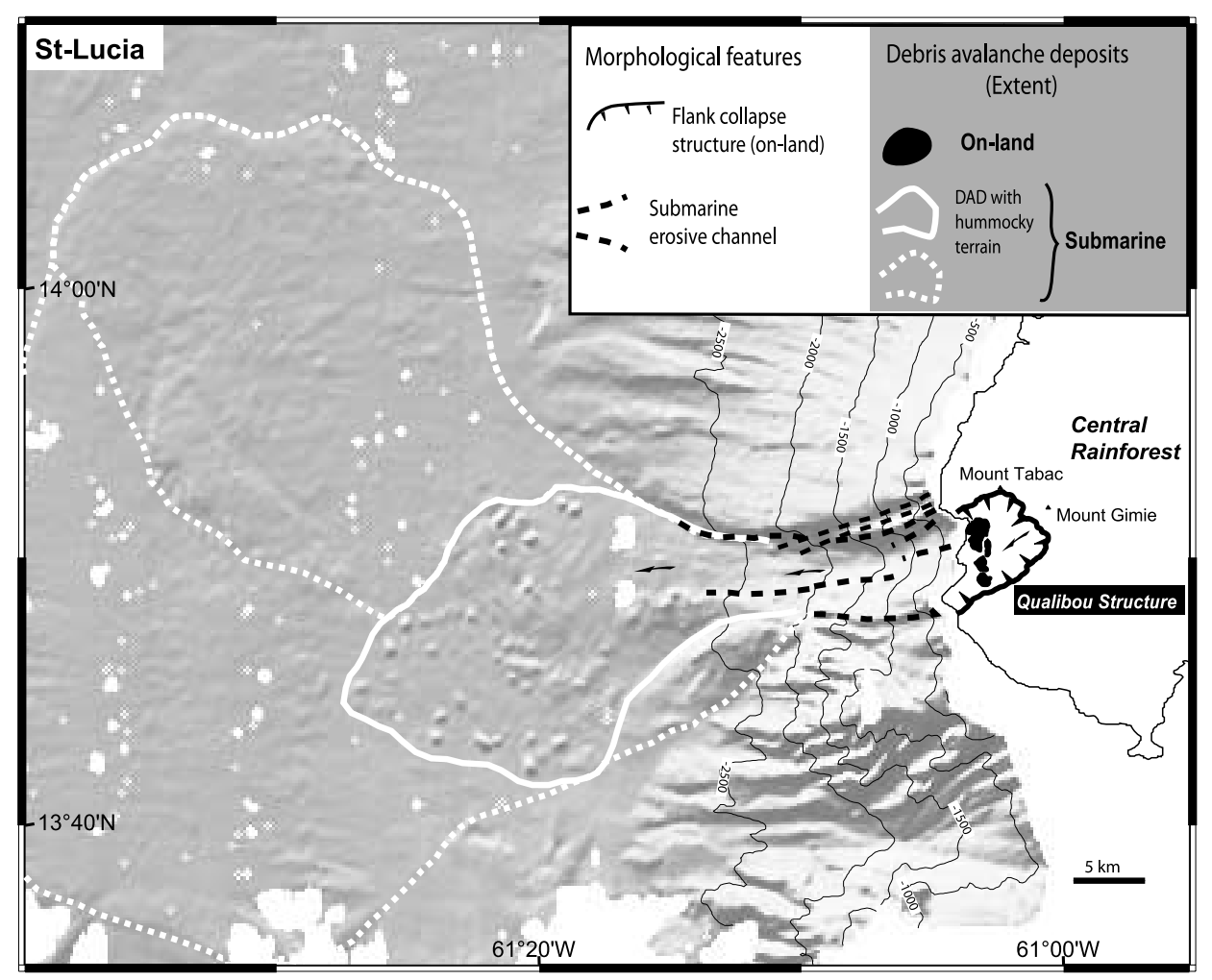

Figure 11. Shaded image of bathymetry west of St. Lucia illuminated from $\mathrm{N} 320^{\circ}$, showing the different debris avalanche deposits. The margins of the Qualibou structure and on-land debris avalanche deposits are shown.

the Grenada Basin. The northern and southern rims of the structure show well-defined cliffs up to $100 \mathrm{~m}$ in their upper parts. The eastern rim of the structure is seemingly obliterated by products of the recent Kick 'em Jenny cone. The horseshoe-shaped structure cuts an older volcanic cone, $7 \times$ $12 \mathrm{~km}$ in size, elongated in the N-NW direction. The smooth morphology of the flanks of this cone contrasts with that of the flanks of the platform north and south which are dissected by numerous submarine canyons. More recently, Lindsay et al. [2005a] confirmed this interpretation, on the basis of a new SeaBeam bathymetric survey aboard the NOAA ship Ronald H. Brown. They identified a hummocky mound of material at the opening of the horseshoe-shaped structure that they interpreted as a debris avalanche deposit. Located between 6 and $16.5 \mathrm{~km}$ from the present active volcano, this deposit covers an area of $67 \mathrm{~km}^{2}$ with a mean thickness of $151 \mathrm{~m}$ and a total volume of $10 \pm 0.5 \mathrm{~km}^{3}$. Lindsay et al. [2005a] suggest that this voluminous debris avalanche deposit is the result of the collapse of a much larger (probably emergent) volcano ("proto" Kick 'em Jenny) than the present edifice. The summit of the present active cone of Kick 'em Jenny is only at $180 \mathrm{~m}$ bsl.

\section{Discussion}

\subsection{Abundance of Flank Collapse Events in the Lesser Antilles Arc}

[63] More than 47 flank collapse events have now been documented or inferred in the Lesser Antilles arc. All the events are reported in Table 1, and the large offshore debris avalanches are also reported in Figure 15. Although 13 events were identified on old inactive edifices, the majority was recognized as having occurred in the last $100 \mathrm{ka}$ on active volcanoes. However, this difference is not the result of a greater instability of the active volcanoes in the recent period. Indeed, erosion processes will degrade and redistribute the main parts of the old DADs whereas continued volcanic activity will build new cones infilling the horseshoe-shaped structures and often obliterate the structures of the older events. For volcanoes several hundred thousand years old, only the largest events can be recognized. An example is the large flank collapse event preceding the construction of Pitons du Carbet lava domes on Martinique which is probably one of the most voluminous events of the Lesser Antilles arc $\left(\sim 40 \mathrm{~km}^{3}\right)$. While the deposits and structures of such events can easily be recognized on land (Figure 9), it is more difficult to identify old DADs offshore. In the case of most of these events, this can be explained by the textural characteristic of these DADs, rich in mixed matrix facies material with abundant hydrothermally altered products that will lose their cohesiveness with increased subaqueous travel distance. A significant part of these offshore deposits will thus be remobilized into voluminous and extensive debris flows which cannot be clearly identified in the seismic reflection profiles because they are covered by a thick marine sedimentary sequence. For smaller events it is likely that subaerial deposits were totally eroded or covered by more recent deposits and that the structures were destroyed or completely filled by more recent edifices. 


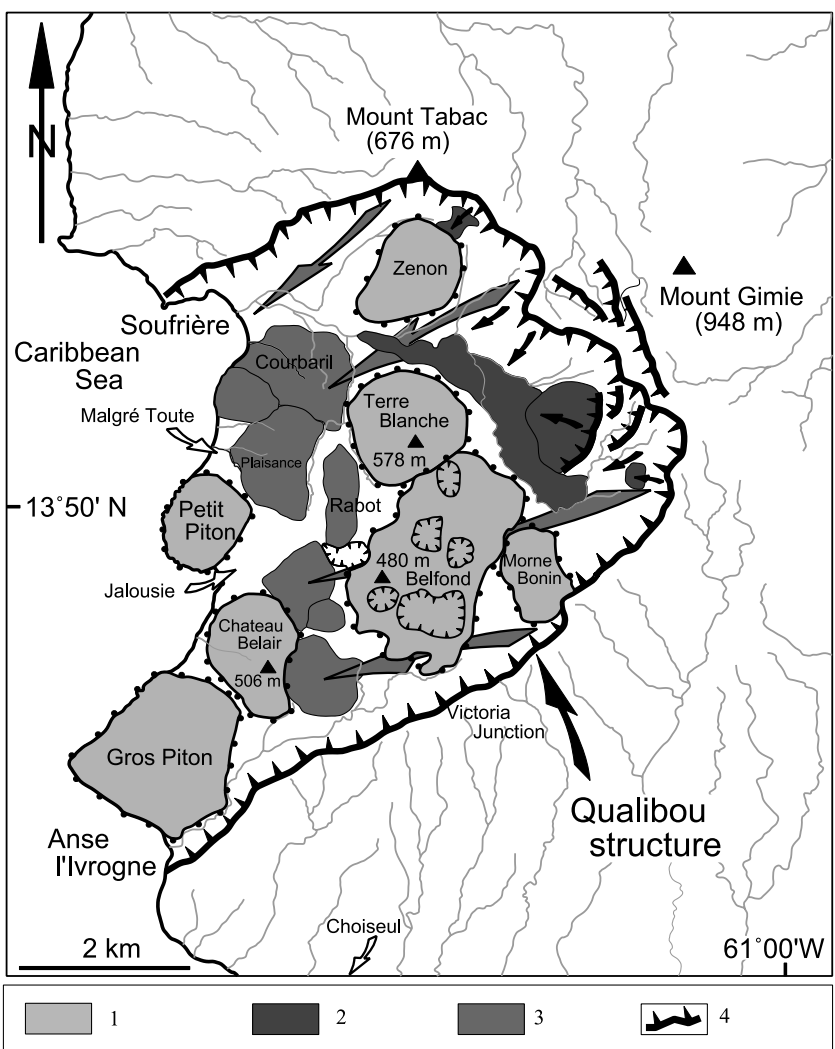

Figure 12. Simplified geological map of the Qualibou structure (St. Lucia). Legend numbers indicate 1, dacitic lava domes; 2, megaslides post flank collapse; 3, debris avalanche deposits (large hummocks); 4, scarps of the flank collapse structure and of the post collapse slides.

[64] Le Friant et al. [2004] has shown that not only the subaerial part of the edifices are destroyed by flank instability but that the submarine flanks of the islands can also be affected by significant slope instability. This is true for the island of Montserrat where a lot of slope failure events have been identified. It is also the case for most of the islands and mainly the islands bordered by the Grenada Basin characterized by steep western submarine flanks. Large flank collapses can destroy not only the aerial part of the edifice but also a part of the submarine flank (e.g., Montagne Pelée, Martinique: 25,000 years old event; Plat Pays volcanic complex, Dominica: second event). Slope failures of the submarine flanks can occur unrelated to subaerial instability.

[65] On most of the active volcanoes, the oldest events are in the order of a hundred thousand years old. They are large events mobilizing several tens of $\mathrm{km}^{3}$ of material. On several volcanoes such as Montagne Pelée or Plat Pays volcanic complex, we observe a decrease in the collapse volume and size of resulting structure with time. Two hypotheses can be proposed. The first hypothesis would suggest that the decrease of the collapse volume with time is related to structural factors. The floor of the horseshoeshaped structure resulting from the first flank collapse represents a discontinuity between old indurated deposits and nonconsolidated deposits of the new cone built inside the structure. It favours the circulation of hydrothermal fluids and meteoric waters and becomes progressively an area where infiltration of meteoric waters will be focused and retained. The circulation of superficial waters along this discontinuity but also along discontinuities inside the more recent cone will create areas of mechanical weakness that will promote recurrent sliding. The load necessary for the successive flank collapse events will likely diminish because of continuous development of hydrothermally altered zones and will thus promote a reduced collapse volume. In the second hypothesis, the low-volume events are more underrepresented in older sequences because their deposits have been covered and the structures eroded or masked by more recent events. This is probably the case on several volcanoes as suggested by the abundance of flank collapse

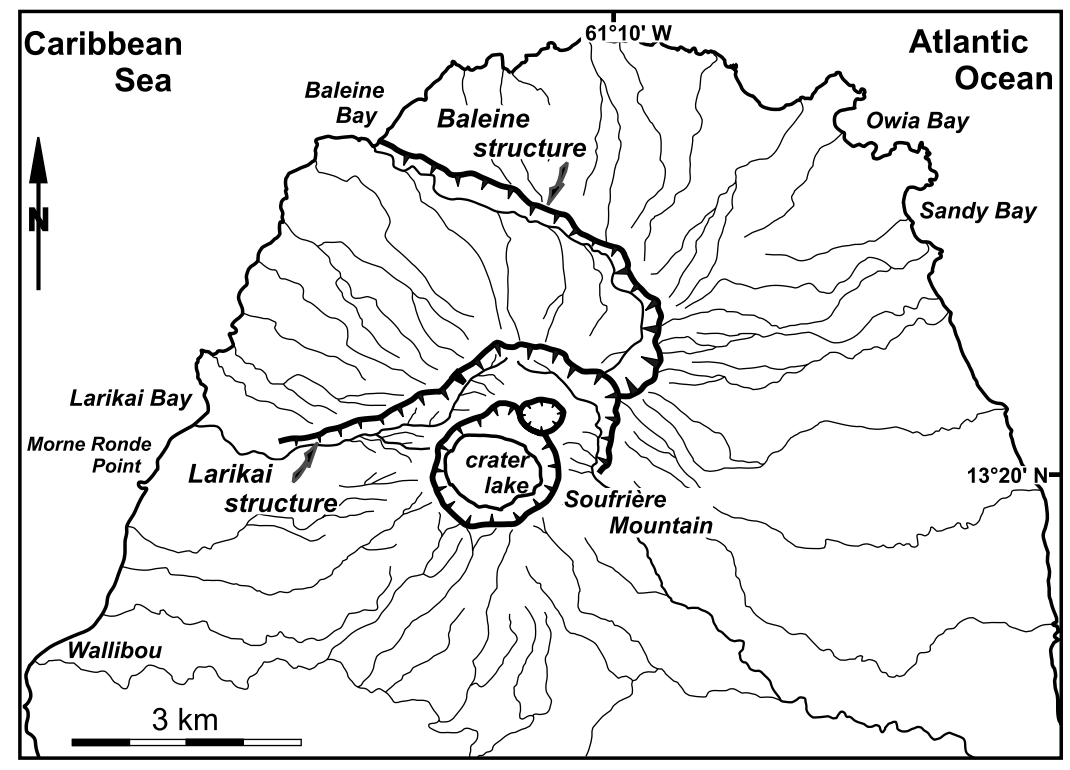

Figure 13. Interpretative map showing the hydrographic system of Soufrière of St. Vincent and the horseshoe-shaped structures of Baleine and Somma. Note the different orientations of the hydrographic system inside and outside the two structures. 


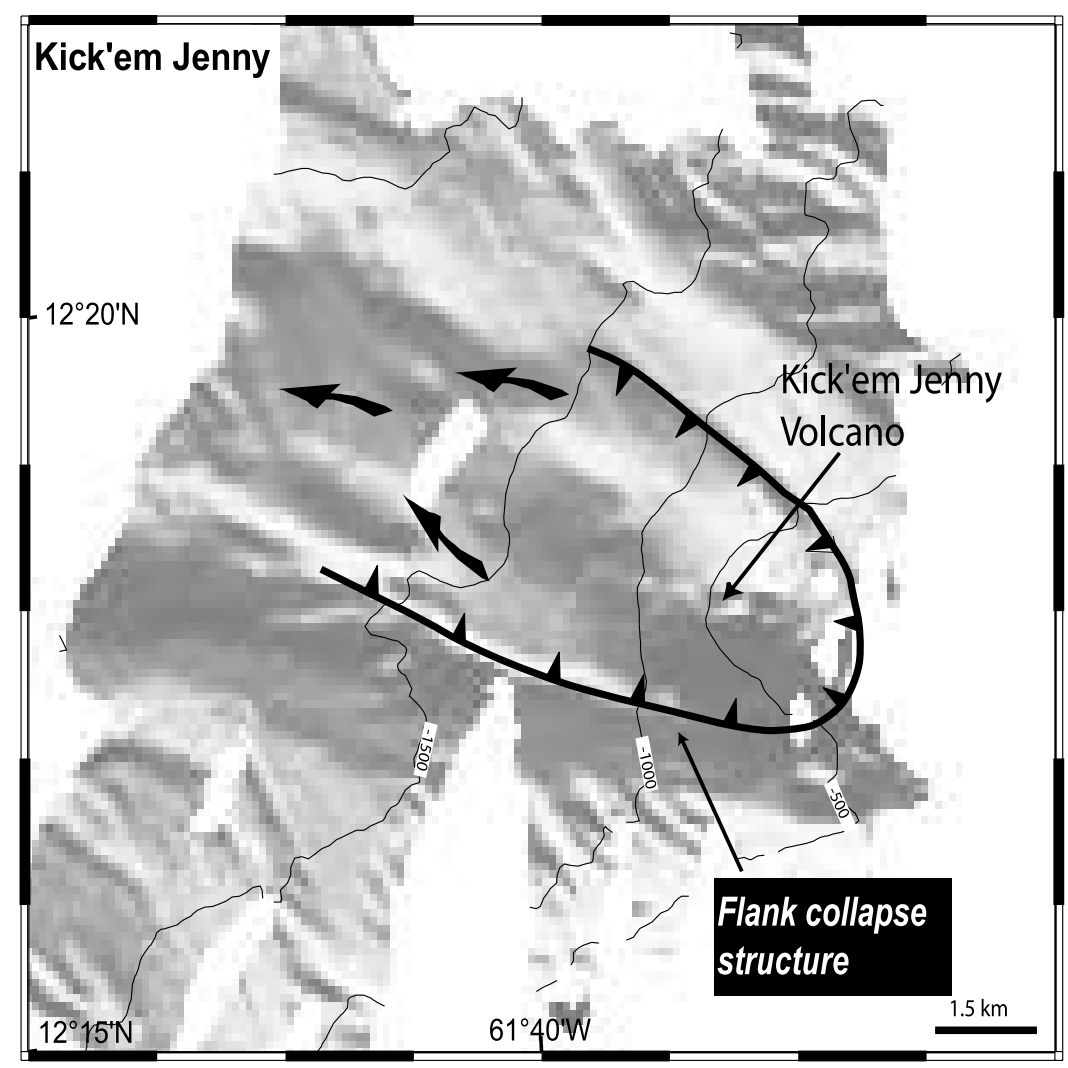

Figure 14. Submarine volcano of Kick 'em Jenny, north of Grenada (cruise Seacarib, 1995), located inside a horseshoe-shaped structure transecting an older cone ("proto" Kick 'em Jenny).

events in the recent period. In this case we have probably underestimated the number of flank collapse events which occur on these volcanoes.

\subsection{Origin of the Flank Collapses}

[66] Active volcanoes in the northern part of the arc evolve distinctly from those in the south. On the active volcanoes of the northern islands (Soufrière Hills, Montserrat, and La Soufrière, Guadeloupe), flank collapses are repetitive, limited to the summit part of the edifices, and thus involve low volumes $\left(<0.1 \mathrm{~km}^{3}\right.$ to $\left.\mathrm{km}^{3}\right)$. They may occur along different directions (Soufrière Hills, Figures 3 and 4) or may repetitively affect the same flank of the volcano (La Soufrière of Guadeloupe, Figure 5). In the southern islands (Dominica to Grenada), however, flank collapses are less frequent, systematically directed toward the west, and lead to debris avalanches that propagate underwater well into the Grenada Basin (Figures 7-15). Here, the avalanches and the recognized collapse structures are voluminous (several $\mathrm{km}^{3}$ to tens of $\mathrm{km}^{3}$ ).

[67] In the northern islands, the 1997 Boxing Day collapse event of Soufrière Hills, Montserrat [Sparks et al., 2002, Voight et al., 2002] provides an excellent scenario for a potential future collapse of La Soufrière, Guadeloupe. Since its onset in 1995, the growth of the Soufrière Hills lava dome occurred mostly within the east facing English's amphitheater crater. As Lopez and Williams [1993] suggested for other sites, the base and walls of this crater had suffered extensive alteration from protracted active hydrothermal circulation. Loading from significant dome growth in December 1997 exceeded the mechanical strength of the old crater and its southwestern wall to culminate on December 26 with the collapse of a part of the edifice and the active lava dome. Evidence from the geological record indicates that in the last 15,000 years the frequency of partial edifice collapse at La Soufrière of Guadeloupe has increased although the volume of the collapses has decreased [Komorowski et al., 2002]. The active volcano has been affected by intense hydrothermal alteration for an extended period of time as evidenced by the high proportion of hydrothermal alteration products in DADs. Prolonged and extensive hydrothermal activity and associated frequent phreatic eruptions, as well as the structural characteristics of the volcanic complex constitute the main geological factors that have controlled recurrent sector collapse of the volcano over the last 15,000 years.

[68] As in the past, well-developed active fracturing in the summit area [Boudon et al., 1989; Komorowski et al., 2002] has led to the formation of interlocked potentially unstable blocks. Collapse structures provide for recurring unstable situations. This is because aquifer water and potentially corrosive hydrothermal fluids preferentially circulate along the discontinuity between the old, generally indurated material of the detachment surface and unconsolidated products of the new cone thus promoting weakening by alteration. Concurrently, progressive loading from reconstruction of volcanic edifices on the steep weakened slopes leads to the next collapse. Judging from the Montserrat Boxing Day event, this loading does not need to be substantial. In the north of the arc, edifice collapse is not 


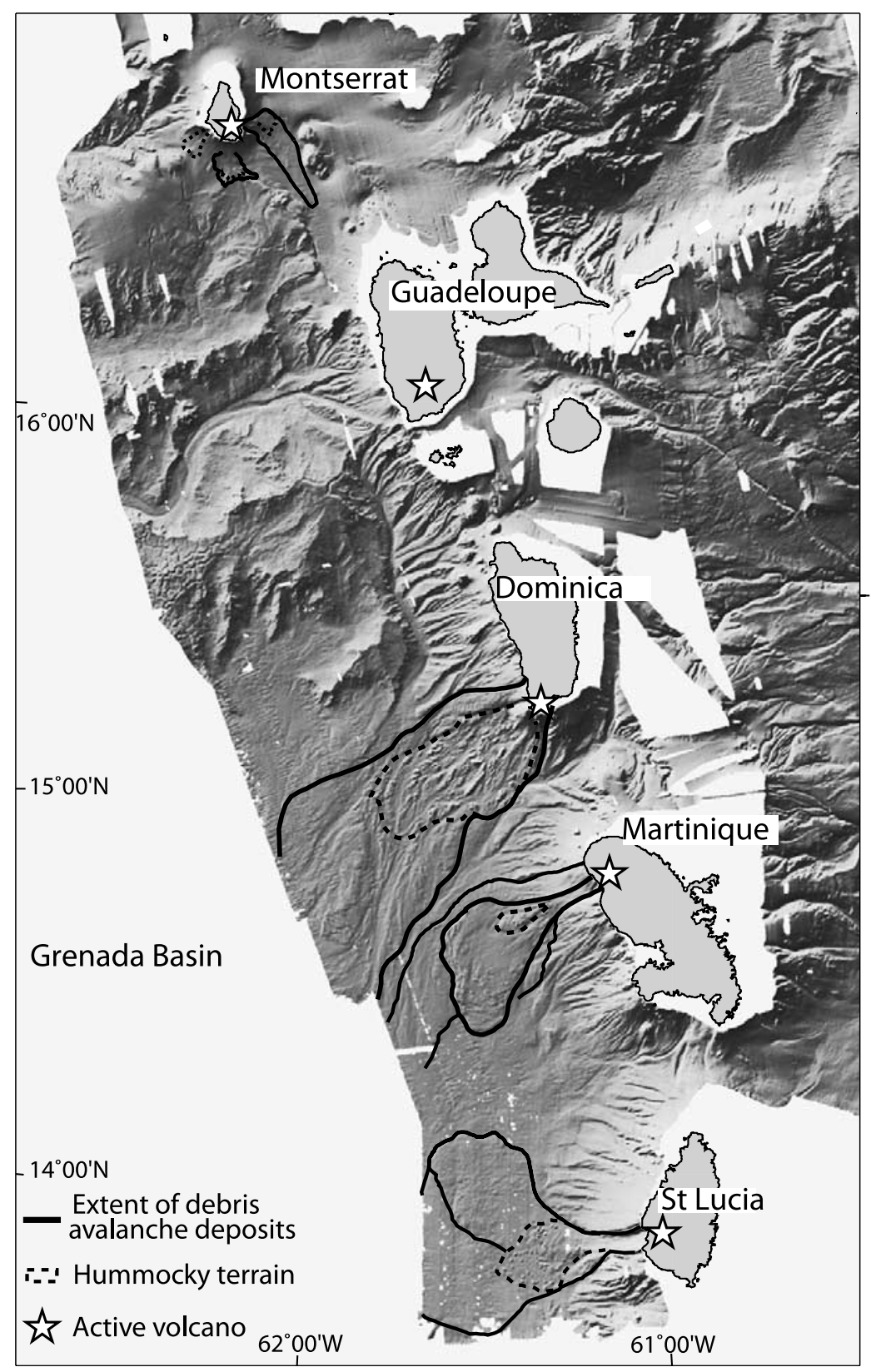

Figure 15. Extent of debris avalanche deposits on the seafloor surrounding the Lesser Antilles Arc (modified from Deplus et al. [2001], copyright 2001, with permission from Elsevier). The main active volcanoes are shown by stars. Limits of the deposits are superimposed on the swath bathymetry illuminated from $\mathrm{N} 320^{\circ}$. Thick black lines indicate the extent of the main debris avalanche deposits and dotted black lines the deposits with a characteristic hummocky morphology.

restricted to a particular direction except toward buttressing older and inactive volcanic structures.

[69] The magmatic origin of some flank collapses is clear for some events as for example the Boxing Day event on Montserrat [Sparks et al., 2002] or the 3.1 ka eruption of La Soufrière of Guadeloupe [Boudon et al., 1984] where blast deposits rich in juvenile vitric andesite fragments and ${ }^{14} \mathrm{C}$ dated charcoal fragments were recognized and studied. However, in most other cases, the magmatic component is difficult to establish because of the difficulty of preserving it from erosion or of recognizing widespread but relatively thin magmatic blast deposits. Current studies on La Soufrière of Guadeloupe are in progress to identify new blast deposits and their magmatic component.

[70] Because of the low collapse rate of southern volcanoes, the compounded load of successive eruptions grows to greater volumes before each event providing for voluminous DADs. Moreover, the contrasting geodynamic setting of southern islands is such that they are bordered to the west by the deep Grenada Basin, and do not have an older island arc crust to the east (Figure 1 and Bouysse et al. [1990]). This results in a significant asymmetry of their on-land and 


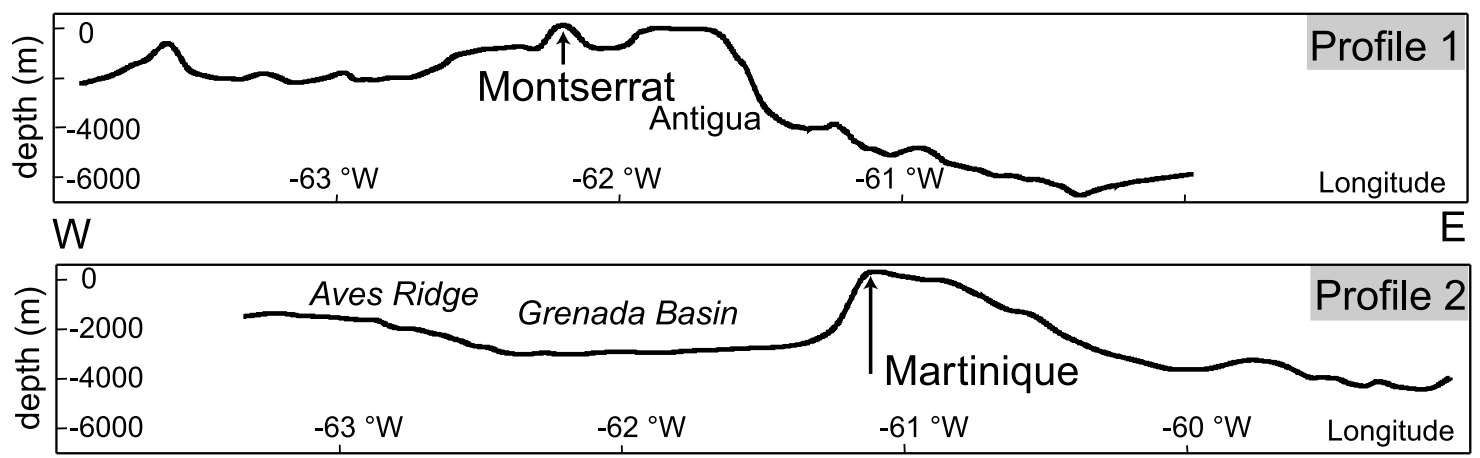

Figure 16. Topographic profiles through the arc from west to east. Profile 1 is Montserrat, profile 2 is Martinique. The location of the two profiles is given in the Figure 1.

underwater slopes which averages $20 \%$ to the west, and only $5 \%$ to the east (Figure 16). This asymmetry is increased by the location of the volcanic edifices, which is shifted for most of them to the west. The load created by the volcanic cone associated with the significant slopes of the subaerial and submarine western flank is one of the more important factors in generating the instability of these volcanoes. After a flank collapse, a new cone will grow inside the large resulting horseshoe-shaped structure. The floor of the structure is a discontinuity between more indurated products of the old volcanic edifice and the less consolidated products of the recent cone. This discontinuity favours the circulation of the fluids along its surface and in the upper part of the new cone (hydrothermal fluids and meteoric waters infiltrated in the new and more permeable products of the new cone). Thus increased pore fluid pressure will promote a reduction of basal friction along the zones of circulation and at geological interfaces and create weakness areas that can favour new flank collapses. Hence the new cone located in the structure can become unstable before reaching a volume similar to the precedent cone. This will favour subsequent flank collapses of smaller volumes but at a greater temporal frequency (e.g., Montagne Pelée and Plat Pays volcanic complex).

[71] Rapid and significant sea level variations can also have an influence on the stability of the volcanic edifices. A rapid lowering of the sea level, similar to the one produced during the last glacial period, modifies the pore pressure at the base of the volcanic edifice and increases the pressure difference with the external environment. It may thus constitute a destabilizing factor [McGuire, 1996; McGuire et al., 1997; Keating and McGuire, 2004]. The second flank collapse of Montagne Pelée, dated $25 \mathrm{ka}$, occurred during a significant decrease in sea level. Moreover a rapid rise of sea level is likely to have an even more significant effect on the stability of the volcanoes.

\subsection{Morphology and Texture of the DADs in the Lesser Antilles Arc}

[72] Different morphologies and textures are observed in the DADs related to the 47 flank collapse events identified in the Lesser Antilles arc. They depend on two main factors: (1) the nature of the products which constitute the flanks of the volcano and (2) the volume of the flank collapse. For the volcanoes of the northern part of the arc (Montserrat and Guadeloupe), the debris avalanches result essentially from the collapse of the highly fractured and hydrothermally altered summit parts of the volcano. No massive lava megablocks are observed. Megablocks are composed predominantly of soft hydrothermal products originating from specific different areas of the hydrothermal system. The abundance of closely spaced megablocks with a decametric maximum size forms a characteristic hummocky morphology as exemplified by the 1997 debris avalanche of Soufrière Hills on Montserrat [Voight et al., 2002]. However, this hummocky morphology will be progressively smoothed as a result of erosion of nonconsolidated products of avalanche megablocks and also of deposition of postcollapse volcaniclastic materials such as lahars and block-and-ash flows. Therefore hummocky morphology is not preserved for older deposits such as the 2000 years old English's event of Montserrat or for the last DADs of La Soufrière of Guadeloupe. Postcollapse secondary remobilization of avalanche material when saturated by water can partially obliterate primary hummocky morphology. Deposition of intrahummock detrital sediments from reworking of the deposit will also contribute to a smoother upper surface.

[73] Extensive fracturing and hydrothermal alteration will contribute to the weathering of lava flows and domes and to a decrease in the mechanical integrity of the source edifice. Flank collapse will promote additional fragmentation and emplacement of material as an avalanche block facies or a generally dominant mixed block-and-matrix facies. Avalanche blocks are pieces of the volcanic edifice with a size that can vary from centimetres to metres or even kilometres which have been transported from their source position on the edifice over a distance sometimes of tens of kilometres in a more or less coherent manner and without full disaggregation. Avalanche blocks are constituted of individual fragments or clasts which are consolidated coherent solid particles of millimetric to metric size. Avalanche blocks display variable degrees of fracturing and are often characterized by fractured clasts displaying a jigsaw fit of individual broken but continuous or weakly dispersed angular fragments. The mixed facies or matrix facies of the avalanche consists of a mixture of smaller deformed avalanche blocks. These blocks are set in a finer-grained heterogeneous nonsorted and nonstratified matrix of avalanche material often dominated by hydrothermally altered debris. Reaction of hydrothermal minerals (e.g.; sulfates, sulfur, clays, sulfides, silica) with the atmosphere and surface water 
will lead to rapid induration and cementation of parts of the avalanche deposit (block as well as mixed facies). DADs are dominated by transported hydrothermal material sourced in the precollapse buried hydrothermal system and from fumarolic and altered zones on the flanks of the edifice. Thus on many volcanoes, DADs have been for a long time interpreted as lahar deposits in spite of their large extent and volume, their distribution also as nonchanneled overspill units, their significant thickness and the presence of megablocks made of hydrothermal products.

[74] In the case of large flank collapse events characteristic of volcanoes of the southern part of the Lesser Antilles arc, two types of morphology and texture are observed. The first type can be illustrated by the mostly submarine DADs of the Plat Pays volcanic complex in Dominica. The deposits have a characteristic hummocky morphology with megablocks several kilometers long and several hundreds of meters high (Figures 7 and 15). This morphology is well preserved offshore and in spite of a diminution of size with distance, megablocks are present $50 \mathrm{~km}$ from their source. On land, where we can observe their texture, the megablocks are made of massive lava displaying the characteristic jigsaw fit of fractured areas (Figure 2). These debris avalanches resulted from collapse of a volcano constituted essentially of lava domes and lava flows. This is in agreement with the nature of the cone located inside the horseshoe-shaped structures. The second type corresponds to the debris avalanche of Montagne Pelée, whose offshore morphology is smoother with fewer megablocks. This is also in agreement with the nature of Montagne Pelée volcano, constituted principally of pyroclastic deposits (ash-and-pumice falls and flows, block-and-ash flows), lava domes being present only in the summit part of the edifice.

\subsection{Implications of Flank Collapse on the Evolution of the Volcanoes and the Islands}

[75] As proposed by several authors, flank collapse events have a significant influence on the evolution of volcanic edifices. In the case of the Lesser Antilles they also control the morphology of the islands.

\subsubsection{Effect on the Magma Composition and Magmatic Production Rate}

[76] Voluminous flank collapse events, such as those that have affected volcanoes of the southern part of the arc, produce a decrease in the load on the magmatic reservoir and feeding conduits. The threshold effect on the density contrast necessary for magma ascent produced by the edifice is thus reduced. This leads to an increase in the magma production rate and in the ascent of denser and more basic magmas as proposed by Pinel and Jaupart [2000]. This effect can be clearly illustrated on Montagne Pelée by the relationships between the second flank collapse dated at $25 \mathrm{ka}$, and the successive magmatic activity [Boudon et al., 2002]. Indeed, acidic andesites were erupted before the flank collapse event that mobilized $13 \mathrm{~km}^{3}$ of material. After the collapse, basaltic andesites were emitted for several thousand years. Volcanic activity stopped when the new cone was sufficiently voluminous to increase the threshold effect on the magma chamber which stopped the ascent of dense and basic magma. Following an eruptive pause of 2000-3000 years, more differentiated magmas were emitted.
[77] The observation that magma production increases markedly following flank collapse events must also be taken into account in the calculation of magma production rate over a certain time period. Offshore DADs are generally not integrated in the calculation of the volume of the emitted products which is typically based on the volume of the subaerial cone, the volume of the pyroclastic products deposited into the sea and of the volume of eroded material. In the case of repetitive and small flank collapses as on Soufrière Hills on Montserrat or on La Soufrière of Guadeloupe, the volume of the debris avalanche that flows offshore is not important. For Soufrière Hills volcano on Montserrat, Le Friant et al. [2004] estimated that the volume of offshore debris avalanche is around $1 \mathrm{~km}^{3}$ and represents $3 \%$ of the total volume of the emitted products since the beginning of construction of the volcano $(174 \mathrm{ka})$. On La Soufrière of Guadeloupe, this volume is also small, because the debris avalanches were predominantly deposited on land. In contrast, for the volcanoes of the south part of the arc, the volume of debris avalanches that flowed into the Caribbean Sea is significant. On Montagne Pelée, for example, the volume of volcanic products lost as a result of the three flank collapse events is estimated at $40 \mathrm{~km}^{3}$ [Le Friant et al., 2003]. It represents about $70 \%$ of the present subaerial cone. Taking this into account, we can estimate for Montagne Pelée the total subaerial erupted volume (V) since the beginning of the construction of the cone $(\sim 0.3 \mathrm{Ma})$ and the magma production rate on the basis of the calculation proposed by Le Friant et al. [2004] for Montserrat.We can thus define the total subaerial erupted volume $\mathrm{V}$ as

$$
\mathrm{V}=\mathrm{V}_{\mathrm{p}}+\mathrm{V}_{\mathrm{m}}+\mathrm{V}_{\mathrm{e}}+\mathrm{V}_{\mathrm{c}}
$$

$\mathrm{V}_{\mathrm{p}}$ is the volume of the present subaerial cone $\left(\sim 60 \mathrm{~km}^{3}\right)$; $\mathrm{V}_{\mathrm{m}}$ is the volume of the erupted products transported into the sea (pyroclastic flows, tephra fallout and erosion excluding DADs) during the eruptive activity; it is estimated on the basis of the present eruption of Soufrière Hills of Montserrat at $50 \%$ of the total erupted volume. $\mathrm{V}_{\mathrm{e}}$ is the volume of the long-term eroded material and was also estimated for Montserrat to $0.0125 \mathrm{~km}^{3} \mathrm{ka}^{-1}$ [Le Friant et al., 2004] ( $\sim 4 \mathrm{~km}^{3}$ for the $0.3 \mathrm{Ma}$ of activity of Montagne Pelée). $V_{\mathrm{c}}$ is the collapse volume $\left(40 \mathrm{~km}^{3}\right)$. Thus we can write that $\mathrm{Vm}=\left(\mathrm{V}_{\mathrm{p}}+\mathrm{V}_{\mathrm{e}}+\mathrm{V}_{\mathrm{c}}\right) \times 0.5$. For Montagne Pelée $\mathrm{V}_{\mathrm{m}}=$ $52 \mathrm{~km}^{3}$ and we obtain a total erupted volume $\mathrm{V}=156 \mathrm{~km}^{3}$ for the 0.3 Ma of activity of Montagne Pelée. We can deduce a minimum magma production rate of $0.52 \mathrm{~km}^{3}$ $\mathrm{ka}^{-1}\left(0.016 \mathrm{~m}^{3} \mathrm{~s}^{-1}\right)$. This rate is only $0.30 \mathrm{~km}^{3} \mathrm{ka}^{-1}$ $\left(0.0095 \mathrm{~m}^{3} \mathrm{~s}^{-1}\right)$ and thus underestimated by $43 \%$ if the volume of the debris avalanche is not included. If we apply this rate to the Lesser Antilles arc, the mean magma production rate of $0.1 \mathrm{~m}^{3} \mathrm{~s}^{-1}$ proposed by Sigurdsson et al. [1980] for the last 100,000 years of activity of the arc will thus be significantly underestimated.

\subsubsection{Effect on the Geometry of the Volcano}

[78] Following a large flank collapse event, eruptive activity will preferentially develop inside the resulting horseshoe-shaped structure. Ascending magmas will take advantage of the weakened area created by the collapse structure to erupt within it thus forming a new cone displaced with respect to the first cone preferentially in 
the direction of the collapse. Pyroclastic flows and lava flows will be predominantly channelled inside the structure and toward its opening. The central portion of the volcano will be progressively displaced and the edifice will become more asymmetric and thus more unstable in the same direction. We believe that these processes contribute significantly to instability of the western flanks of the volcanoes of the southern part of the arc.

\subsubsection{Effect on the Sedimentation in the Basins}

[79] Flank collapse events in the Lesser Antilles arc deliver voluminous amounts of volcanoclastic material from the islands to the back-arc Grenada Basin and thus modify considerably the sedimentation processes and sedimentation rates. Different processes and types of volcaniclastic material can be considered:

[80] 1. Emplacement of debris avalanches associated with large events from the southern part of the arc involves a great input of volcanoclastic material $\left(\mathrm{km}^{3}\right.$ to tens of $\left.\mathrm{km}^{3}\right)$ in the Caribbean Sea. In the last 100000 years, about $110 \mathrm{~km}^{3}$ of debris avalanches were generated through the whole arc, predominantly in the southern part and deposited into the Grenada Basin. Most of this material is deposited as primary debris avalanches, but a part of it is remobilized as secondary debris flows and turbidites.

[81] 2. Debris avalanches have a significant erosional potential. They produce large and deep troughs on the submarine flanks of the volcanoes as can be clearly observed on the flanks of Montagne Pelée (Martinique) and of Soufrière Hills volcano (Montserrat) (Figures 4 and 8) [ Le Friant et al., 2003, 2004]. Similar troughs are also observed on the submarine flanks of St. Lucia, west of the Qualibou structure (Figure 11). These sediments are incorporated into the debris avalanche and remobilized from the submarine flank of the islands to the Grenada Basin. On Montagne Pelée, the volume of the missing sediments inside the trough associated with the second 25,000 years old debris avalanche deposits is estimated to $1.5 \mathrm{~km}^{3}$. Therefore the dynamics of sedimentary processes will be strongly affected by submarine emplacement of debris avalanches. On the basis of their interpretation of seismic reflection data, Deplus et al. [2001] proposed that debris avalanches erode the upper sedimentary layers of the basin thus likely incorporating a large amount of sediment during transport and disturbing the lower layers.

[82] 3. In the northern part of the arc, as on La Soufrière of Guadeloupe, debris avalanches predominantly deposit material on land. This is essentially due to the smaller volume of the edifice collapse events and the position of the source volcano further away from the coastline. Postdepositional erosion of the debris avalanche deposits will contribute a significant volume of detrital material into the sea. Most of this material is delivered to the Grenada Basin via two deep and extensive submarine canyons which drain the western flank of the northern islands (Figures 2 and 15).

[83] 4. After a flank collapse event, the equilibrium profiles of the terrestrial drainage system will be drastically modified. Rates of erosion and detritic sedimentation in the Grenada Basin will be increased. Offshore from Montagne Pelée volcano, sedimentary layers, several tens of meters thick cover the central part of the second debris avalanche deposit [Le Friant et al., 2003]. They are likely the result of this enhanced sedimentation. These deposits, located at the opening of the trough, will preferentially channel into the deeper Grenada Basin most of the detrital material eroded from the western flank of the volcano where pyroclastic activity is dominant.

[84] On the basis of piston core studies on both sides of the arc, Reid et al. [1996] have determined that sedimentation rates display spatial variations. They are higher to the west of the arc and they increase from north to south with a maximum in the southern part of the Grenada Basin. Some temporal variations are detected. Enhanced erosion characteristic of sea level low stands will promote an increase in sedimentation rates compared to conditions prevailing during sea level highstands. Rates vary from 4 to $23 \mathrm{~cm} \mathrm{ka}^{-1}$ during the Holocene $(0-12,000$ years) sea level highstand and reach larger values (from 9 to $>25 \mathrm{~cm} \mathrm{ka}^{-1}$ ) during the second period of the Wisconsin glaciation $(35,000-$ 12,000 years). We show that flank collapse events played a significant role in this distribution. In addition to generating debris avalanches and associated debris flows and turbidites in the Grenada Basin, these events have significantly contributed to volcanogenic and detrital sedimentation by multiple processes, including an increase in the erosion after flank collapse, and an increase in sediment production rate (due to direct fallout by atmospherically dispersed plumes, entrance of pyroclastic flows into the sea, rapid remobilization of subaerial tephra by fluvial and eolian processes). Most of these sediments are transported into the back-arc Grenada Basin, directly, by the two main submarine valleys which drain the western flank of the northern islands but also by surface currents which transport volcaniclastic material through the interisland channels from the east to the west into the back-arc basin.

\subsection{Hazard Produced by Flank Collapses in the Lesser Antilles}

[85] As of today, at least 47 volcano collapse events have been identified in the Lesser Antilles arc of which about 15 occurred in the last 12,000 years on active volcanoes. Eyewitness accounts and studies of the Mount St. Helens event in 1980 [Lipman and Mullineaux, 1981] and the much smaller Boxing Day event on Montserrat in 1997 [Sparks et al., 2002, Voight et al., 2002] underscore their highly devastating effect on land, particularly on a small island.

[86] In the northern Caribbean arc, the potential for future volcano collapses is high. The DADs from the most recent eight events on La Soufrière of Guadeloupe in the last 7700 years cover the same southwestern flank of the volcano (Figure 5). The heavily populated cities of SaintClaude and Basse-Terre (30,000 inhabitants) are located on top of this sequence of deposits which are locally a hundred meters thick. In addition, outcrops of the laterally directed blast deposit associated with the 3100 years B.P. event cover more than $60 \mathrm{~km}^{2}$ in the same area suggesting that the initial blast must have devastated most of the southern part of Basse-Terre island [Boudon et al., 1984]. Blast deposits associated with some of the other events have been discovered recently [Komorowski et al., 2002, 2005]. The formation of La Soufrière lava dome, around 1530 A.D. (G. Boudon, manuscript in preparation, 2007), during the last magmatic eruption of the volcano, was preceded by a small flank collapse event with emplacement of a debris avalanche that reached the sea $9 \mathrm{~km}$ away. 
[87] Several lines of evidence indicate that presently La Soufrière of Guadeloupe lava dome is potentially unstable: (1) the lava dome which is built on a S-SW sloping older collapse surface (G. Boudon, manuscript in preparation, 2007) and is cut by a series of radial fractures opened by the successive phreatic eruptions that occurred during historical time, one of which is linked to a local active normal fault; (2) most of the lava dome, its basement and its surroundings are weathered by prolonged and intense hydrothermal activity; (3) hydrothermal fluid circulation occurs preferentially along S-SW oriented older collapse structure surfaces; and (4) we have observed a sustained and significant fumarolic reactivation, associated with low-energy shallow depth seismic swarms since 1992 [Komorowski et al., 2005]. Initial results of the simulation of a flank collapse of the present lava dome $\left(0.05 \mathrm{~km}^{3}\right)$ show that the debris avalanche will cover an area similar to the preceding events, including the cities of St. Claude and Basse-Terre [Le Friant et al., 2006]. There is a high probability that edifice collapse will trigger laterally directed explosions that have the potential of covering an area of 30 to $80 \mathrm{~km}^{2}$ in southern Basse-Terre. This is particularly true if they are associated with a magmatic eruption and thus involve high-temperature gases and rock debris as was the case in the largest of these events about 3100 years ago [Boudon et al., 1984]. The entry of a debris avalanche into the sea will generate a hazardous tsunami that could have direct effects on the population concentrated near the Caribbean coast (most likely) or the Atlantic coast (least likely) of southern Basse-Terre, as well as the rest of coastal Guadeloupe and elsewhere in the Caribbean. Material from debris avalanches ponded in one or several river drainages will likely form temporary dams that could burst, triggering devastating flooding. Ponded DADs will be remobilized by debris flows for a long time following the eruption.

[88] The Boxing Day event on 26 December 1997 of the Soufrière Hills volcano on Montserrat [Sparks et al., 2002; Voight et al., 2002; Young et al., 2002] is a very good analogue for the small-volume debris avalanches that represent the most hazardous of the high-probability future events for La Soufrière of Guadeloupe. Moreover the eruptive record of La Soufrière of Guadeloupe clearly indicates that they have occurred as part of all other eruptive scenarios (i.e., phreatic eruptions, dome-forming eruptions, or large open crater explosive eruptions) [Komorowski et al., 2005].

[89] Since the Boxing Day event in 1997, the eruption of Soufrière Hills volcano (Montserrat) has consisted of a succession of lava dome growth phases interrupted by short periods of destruction by gravitational collapse. In July 2003, the lava dome had reached a maximum elevation and was destroyed by a succession of collapses directed to the east. A significant volume of the products (estimated to be $210 \times 10^{6} \mathrm{~m}^{3}$ ) flowed into the sea [Herd et al., 2005] and triggered a small tsunami on the northwestern coast of Guadeloupe $50 \mathrm{~km}$ away that destroyed small boats in the harbor of Deshaies (F. Beauducel and S. Bazin, unpublished data, 2003). A similar event occurred on 20 May 2006 triggering another small tsunami on the northwestern coast of Guadeloupe.

[90] In the southern Caribbean arc, voluminous collapses have involved the entire southwestern flank of the volcanoes down to sea level and probably below. The catastrophic effects on land are compounded with the sudden entry into the sea of several $\mathrm{km}^{3}$ or tens of $\mathrm{km}^{3}$ of debris likely to have generated tsunamis several tens of meters high. In addition to the source island, they would most probably have affected all coastal areas of the arc and threatened densely populated shorelines of the Greater Antilles and Central America as was discussed for the first time for Kick'em Jenny volcano by Smith and Shepherd [1993].

[91] An assessment of the stability conditions of volcanoes of the arc is thus necessary in conjunction with careful monitoring of slope instability for edifices that are particularly prone to future collapse based on factors such as size, degree and efficiency of hydrothermal alteration, fracturing and faulting, ongoing volcanic activity. As discussed above, volcanoes with a horseshoe-shaped collapse structure filled with a new voluminous cone will be particularly liable to future collapse. Thus the triggering of future collapses may not require a loading in excess of that involved in past events. At Montagne Pelée (Figure 9), for instance, the floor of the 25,000 year horseshoe-shaped structure forms a prominent interface along which hot and cold water circulation has developed [Zlotnicki et al., 1998]. A new edifice was built but collapsed long before it reached the size of the older structure. Today, partial collapse of the new voluminous active cone (several $\mathrm{km}^{3}$ ) that partly fills the upper part of the two recent collapse structures constitutes, as in Guadeloupe, a highly plausible geological scenario whose risks must be taken into consideration. With its past record of collapse, the highly active submarine Kick'em Jenny volcano (Figure 9) NW of Grenada is particularly prone to future collapse with a clear tsunamigenic threat.

[92] Monitoring of edifice slope stability by GPS and EDM techniques is now operational in the two volcanological and seismological observatories of Guadeloupe and Martinique. On Soufrière Hills, the Montserrat Volcano Observatory has maintained since the beginning of the crisis in 1995 a significant multitechnique deformation monitoring network (GPS, EDM, photogrametry, ground radar) combined with visual observations. The growth of successive lava domes has been documented and analyzed in detail. Thus thresholds for excessive size and the increased likelihood of instability were established and monitored as for example before the Boxing Day collapse [Young et al., 2002; Voight et al., 2002] and the collapse of July 2003. New techniques for mapping and monitoring the evolution of hydrothermal alteration and physicochemical processes that promote mechanical instability of volcanoes must be developed for all active volcanoes of the Lesser Antilles as they have been developed at Mount Rainier, Mount Hood and Citlatépetl [Crowley and Zimbelman, 1997; Watters et al., 2000; Finn et al., 2001; Reid et al., 2001; Zimbelman et al., 2004].

[93] Monitoring of slope stability is particularly necessary for volcanoes such as La Soufrière of Guadeloupe, Montagne Pelée (Martinique), Plat Pays volcanic complex on Dominica or Soufrière of St. Vincent, where a large new cone is located in the horseshoe-shaped structure. This is necessary not only for the population of each island concerned but also to a variable degree for populations of the Lesser Antilles arc and probably of the Greater Antilles. Indeed, most of these populations live primarily on the 
coastline and are thus exposed to the impact of potential volcanogenic tsunamis which deserve further detailed analysis and modeling.

[94] Acknowledgments. We thank R. S. J. Sparks and B. Villemant for fruitful discussions. We are grateful for the detailed review of the paper by B. McGuire and L. Siebert and their constructive comments which improved the manuscript. We thank also the staff of the two Volcanological and Seismological Observatories of Guadeloupe and Martinique for logistical help. We are also grateful to the staff of the Montserrat Volcano Observatory for their scientific input, and welcome during difficult times. The AGUADOMAR and CARAVAL cruises would not have been so successful without the experience of the captains and crew of $\mathrm{R} / \mathrm{V}$ L'Atalante, and the animated discussions with the participating scientists. Cruises were funded by IFREMER, France. CNRS/INSU, France, provided financial assistance through several programs (PNRN, Océan, ACI). Digital elevation models for Guadeloupe and Martinique were provided by IGN (France) and for Montserrat by G. Wadge. Partial fieldwork for Montserrat and Guadeloupe was funded by the EXPLORIS European Community research project (EVR1-CT-2002-40026). We thank M. Paterne at LSCE (Gif sur Yvette, France) for radiocarbon dates funded by EXPLORIS. This is IPGP contribution 2207.

\section{References}

Anderson, T., and J. S. Flett (1903), Report on the eruption of the Soufrière of Saint-Vincent in 1902 and on a visit to montagne Pelée in Martinique, Philos. Trans. R. Soc. London, 200, 353-553.

Aspinall, W. P., H. Sigursson, and J.B. Shepherd (1973), Eruption of Soufrière Volcano on St. Vincent Island, 1971-1973, Science, 181, $117-$ 124.

Barrabé, L., and J. Jolivet (1958), Les récentes manifestations d'activité de la Guadeloupe (Petites Antilles), Bull. Volcanol., 19, 143-158.

Béget, J. E., and J. Kienle (1992), Cyclic formation of debris avalanches at Mount St. Augustine volcano, Nature, 356, 701-704.

Belousov, A., M. Belousova, and B. Voight (1999), Multiple edifice failures, debris avalanches and associated eruptions in the Holocene history of Shiveluch volcano, Kamchatka, Russia, Bull. Volcanol., 61, 324-342.

Blanc, F. (1983), Corrélations chronologiques et géochimiques des formations volcaniques du sud de la Basse Terre de Guadeloupe (Petites Antilles), thesis, 171 pp., Univ. of Grenoble, Grenoble, France.

Boudon, G., M. P. Semet, and P. M. Vincent (1984), Flank failure-directed blast eruption at Soufrière, Guadeloupe, French West Indies: A 3,000-yrold Mt St Helens?, Geology, 12, 350-353.

Boudon, G., M. P. Semet, and P. M. Vincent (1987), Magma and hydrothermally driven sector collapses: The 3100 and $11,500 \mathrm{y}$. B. P. eruptions of la Grande découverte (La Soufrière) volcano, Guadeloupe, French West Indies, J. Volcanol. Geotherm Res., 33, 317-323.

Boudon, G., J. Dagain, M. P. Semet, and D. Westercamp (1988), Notice explicative de la carte géologique au 1/20.000 ème du massif volcanique de la Soufrière (Département de la Guadeloupe, Petites Antilles), 43 pp., BRGM, CNRS, DRM, IPGP, Paris

Boudon, G., M. P. Semet, and P. M. Vincent (1989), The evolution of la Grande Découverte (La Soufrière) volcano, Guadeloupe, F. W. I., in Volcano Hazards: Assessment and Monitoring, IAVCEI Proc. Volcanol., vol. 1, edited by J. Latter, pp. 86-109, Springer-Verlag, New York.

Boudon, G., M. P. Semet, and P. M. Vincent (1992), Major flank collapse at Pitons du Carbet volcano, Martinique: One of the largest similar structures in the Lesser Antilles arc, paper presented at International Geological Congress, Geol. Soc. of Jpn., Kyoto, Japan, 24 Aug. to 3 Sept.

Boudon, G., B. Villemant, J.-C. Komorowski, P. Ildefonse, G. Hammouya, and M. P. Semet (1996), The hydrothermal system of Soufrière Hills volcano, Montserrat (West Indies): Chemical, mineralogical, and microtextural signatures in fluids, altered rocks, and 1995-96 tephra, in The Soufrière Hills Eruption, Montserrat, edited by G. Wadge, pp. 31-34, Geol. Soc., London.

Boudon, G., B. Villemant, J.-C. Komorowski, P. Ildefonse, and M. P. Semet (1998), The hydrothermal system at Soufrière Hills volcano, Montserrat (West Indies): Characterization and role in the ongoing eruption, Geophys. Res. Lett., 25, 3693-3696.

Boudon, G., J. C. Komorowski, M. P. Semet, A. Le Friant, and C. Deplus (1999), Frequent volcanic flank collapses in the lesser Antilles Arc: Origin and hazards. (abstract), Eos Trans. AGU, 80(46), Fall Meet. Suppl., F1142.

Boudon, G., B. Villemant, and A. Le Friant (2002), Relations entre activité volcanique, structure de l'édifice et évolution pétro-géochimique des magmas émis par la Montagne Pelée, paper presented at Réunion des Sciences de la Terre 2002, Soc. Géol. de France-Soc. Fr. de Minéal. Et Cristallogr., Nantes, France, 9-12 April.
Bouysse, P., A. Mascle, A. Mauffret, B. Mercier de Lépinay, I. Jany, A. Leclère-Vanhoeve, and M. C. Montjaret (1988), Reconnaissance de structures tectoniques et volcaniques sous-marines de l'arc récent des Petites Antilles: Kick 'em Jenny, Qualibou, Montagne Pelée, N-W de la Guadeloupe), Mar. Geol., 81, 261-287.

Bouysse, P., D. Westercamp, and P. Andreieff (1990), The Lesser Antilles Island Arc, Proc. Ocean Drill. Program Sci. Results, 110, 29-44.

Carlut, J., X. Quidelleur, V. Courtillot, and G. Boudon (2000), Paleomagnetic directions and $\mathrm{K} / \mathrm{Ar}$ dating of $0-1$ Ma lava flows from La Guadeloupe Island (French West Indies): Implications for time average field models, J. Geophys. Res., 105, 835-849.

Cohen, J. K., and J. J. W. Stockwell (1996), CWP/SU: Seismic Unix release 28: A free package for seismic research and processing, Cent. for Wave Phenomena, Colo. Sch. of Mines, Golden.

Crowley, J. K., and D. R. Zimbelman (1997), Mapping hydrothermally altered rocks on Mount Rainier, Washington, with airborne visible/infrared imaging spectrometer (AVIRIS) data, Geology, 2, 559-562.

Deplus, C., A. Le Friant, G. Boudon, J.-C. Komorowski, B. Villemant, C. Harford, J. Ségoufin, and J.-L. Cheminée (2001), Submarine evidence for large-scale debris avalanches in the Lesser Antilles Arc, Earth Planet. Sci. Lett., 192, 145-157.

Deplus, C., A. Le Friant, G. Boudon, J.-C. Komorowski, S. Sparks, and C. Harford (2002), Numerous DADs off the southern part of Monserrat revealed by recent oceanographic cruises, paper presented at International Congress on Montagne Pelée 1902-2002, IPGP-INSU-IAVCEI, Martinique Island, 12-16 May.

Feuillard, M., C. J. Allègre, G. Brandeis, R. Gaulon, J. L. Le Mouel, J. C. Mercier, J. P. Pozzi, and M. P. Semet (1983), The 1975-1977 crisis of La Soufrière de Guadeloupe (F. W. I.): A still-born magmatic eruption, J. Volcanol. Geortherm. Res., 16(3-4), 317-334.

Finn, C. A., T. W. Sisson, and M. Deszcz-Pan (2001), Aerogeophysical measurements of collapse-prone hydrothermally altered zones at Mount Rainier, Nature, 409, 600-603.

Harford, C. (2000), The volcanic evolution of Montserrat, Ph.D. thesis, 195 pp., Univ. of Bristol, Bristol, U. K.

Harford, C. L., M. S. Pringle, R. S. J. Sparks, and S. R. Young (2002), The volcanic evolution of Montserrat using ${ }^{40} \mathrm{Ar} /{ }^{39} \mathrm{Ar}$ geochronology, in The Eruption of Soufrière Hills Volcano, Montserrat, From 1995 to 1999, edited by T. H. Druitt and B. P. Kokelaar, Mem. Geol. Soc. London, $21,93-113$

Herd, R. A., M. Edmonds, and V. A. Bass (2005), Catastrophic lava dome failure at Soufrière Hills Volcano, Montserrat, 12-13 July 2003, J. Volcanol. Geotherm. Res., 148, 234-252, doi:10.1016/j.jvolgeores. 2005.05.003.

Hincks, T., R. S. J. Sparks, P. Dunkley, and P. Cole (2005), Montserrat, in Volcanic Atlas of the Lesser Antilles, edited by J. M. Lindsay et al., pp.146-167, Univ. of the West Indies, Seismic Res. Unit, Trinidad.

Holcomb, R., and R. Searle (1991), Large landslides from oceanic volcanoes, Mar. Geotechnol., 10, 19-32.

Keating, B. H., and W. J. McGuire (2004), Instability and structural failure at volcanic ocean islands and the climate change dimension, Adv. Geophys., 47, 95-147.

Komorowski, J.-C., G. Boudon, M. Semet, B. Villemant, and G. Hammouya (2002), Recurrent flank collapses at Soufrière of Guadeloupe volcano: Implications of acid hydrothermal fluids on edifice stability, paper presented at International Congress on Montagne Pelée 1902-2002, IPGPINSU-IAVCEI, Martinique Island, 12-16 May.

Komorowski, J.-C., G. Boudon, M. Semet, F. Beauducel, C. AnténorHabazac, S. Bazin, and G. Hammouya (2005), Guadeloupe, in Volcanic Atlas of the Lesser Antilles, edited by J. M. Lindsay et al., pp. 65-102, Univ. of the West Indies, Seismic Res. Unit, Trinidad.

Krastel, S., H. U. Schmincke, C. L. Jacobs, R. Rihm, T. M. Le Bas, and B. Alibés (2001), Submarine landslides around the Canary Islands, J. Geophys. Res., 106, 3977-3997.

Labazuy, P. (1996), Recurrent landslides events on the submarine flank of Piton de la Fournaise volcano (Reunion Island), in Volcano Instability on the Earth and Other Planets, edited by W. J. McGuire et al., Geol. Soc. Spec. Publ., 110, 295-306.

Lacroix, A. (1904), La Montagne Pelée et ses Eruptions, 662 pp., Masson et Cie, Paris.

Le Friant, A. (2001), Les déstabilisations de flanc des volcans de l'arc des Petites Antilles: Origines et conséquences, Univ. thesis, 378 pp., Univ. of Paris 7, Paris.

Le Friant, A., G. Boudon, J.-C. Komorowski, and C. Deplus (2002), L'île de la Dominique, à l'origine des avalanches de débris les plus volumineuses de l'arc des Petites Antilles, C. R. Geosci., 334, 235-243.

Le Friant, A., G. Boudon, C. Deplus, and B. Villemant (2003), Large-scale flank collapse events during the activity of Montagne Pelée, Martinique, Lesser Antilles, J. Geophys. Res., 108(B1), 2055, doi:10.1029/ 2001JB001624. 
Le Friant, A., C. L. Harford, C. Deplus, G. Boudon, R. S. J. Sparks, R. A. Herd, and J.-C. Komorowski (2004), Geomorphological evolution of Montserrat (West Indies): Importance of flank collapse and erosional processes, J. Geol. Soc. London, 161, 147-160, doi:10.1144/0016764903-017.

Le Friant, A., G. Boudon, J.-C. Komorowski, P. Heinrich, and M. P. Semet (2006), Potential flank-collapse of Soufrière volcano, Guadeloupe, Lesser Antilles? Numerical simulation and hazards, Nat. Hazards, 39, 381-393.

Lénat, J. F., P. Vincent, and P. Bachèlery (1989), The off-shore continuation of an active basaltic volcano: Piton de la Fournaise (Reunion Island, Indian Ocean): Structural and geomorphological interpretation from Seabeam mapping, J. Volcanol. Geotherm. Res., 36, 1-36.

Lindsay, J. M. (2005), St. Lucia, in Volcanic Atlas of the Lesser Antilles, edited by J. M. Lindsay et al., pp. 219-238, Univ. of the West Indies, Seismic Res. Unit, Trinidad.

Lindsay, J. M., and J. B. Shepherd (2005), Kick 'em Jenny and Ile de Caille, in Volcanic Atlas of the Lesser Antilles, edited by J. M. Lindsay et al., pp. 105-125, Univ. of the West Indies, Seismic Res. Unit, Trinidad.

Lindsay, J. M., J. L. Latchman, R. E. A. Robertson, L. Lynch, J. David, and J. B. Shepherd (2002), The December 2001 eruption of Kick'em Jenny, paper presented at International Congress on Montagne Pelée $1902-$ 2002, IPGP-INSU-IAVCEI, Martinique Island, 12 - 16 May

Lindsay, J. M., M. V. Stasiuk, and J. B. Shepherd (2003), Geological history and potential hazards of the late-Pleistocene to recent Plat Pays volcanic complex, Dominica, Lesser Antilles, Bull. Volcanol., 65, $201-$ 220.

Lindsay, J. M., J. B. Shepherd, and D. Wilson (2005a), Volcanic and scientific activity at Kick'em Jenny submarine volcano 2001-2002: Implications for volcanic hazard in the southern Grenadines, Lesser Antilles, Nat. Hazards, 34, 1-24.

Lindsay, J. M., A. L. Smith, J. M. Roobol, and M. V Stasiuk (2005b), Dominica, in Volcanic Atlas of the Lesser Antilles, edited by J. M. Lindsay et al., pp. 1-47, Univ. of the West Indies, Seismic Res. Unit, Trinidad.

Lipman, P. W., and D. R. Mullineaux (Eds.) (1981), The 1980 Eruptions of Mount St. Helens, 844 pp., U.S. Geol. Surv. Prof. Pap., 1250.

Lipman, P. W., W. R. Normark, J. G. Moore, J. B. Wilson, and E. Gutmacher (1988), The giant submarine Alika debris slide, Mauna Loa, Hawaii, J. Geophys. Res., 93, 4279-4299.

Lopez, D. L., and S. N. Williams (1993), Catastrophic volcanic collapse: Relation to hydrothermal processes, Science, 260, 1794-1796.

Martin-Kaye, P. H. A. (1969), A summary of the geology of the Lesser Antilles, Overseas Geol. Miner. Res., 10(2), 172-206.

Mattioli, G. S., P. E. Jansma, L. Jaramillo, and A. L. Smith (1995), Sector collapse in island arc volcanoes: A digital topographic and bathymetric investigation of the Qualibou Depression, St Lucia, Lesser Antilles, Caribbean J. Sci., 31(3-4), 163-173.

McGuire, W. J. (1996), Volcano instability: A review of contemporary themes, in Volcano Instability on the Earth and Other Planets, edited by W. J. McGuire et al., Geol. Soc. Spec. Publ., 110, 1-23.

McGuire, W. J., R. J. Howarth, C. R. Firth, A. R. Solow, A. D. Pullen, S. J. Saunders, I. S. Stewart, and C. Vita-Finzi (1997), Correlation between rate of sea-level change and frequency of explosive volcanism in the Mediterranean, Nature, 389, 473-476.

Moore, J. G., D. A. Clague, R. T. Holcomb, P. W. Lipman, W. R. Normark, and M. E. Torresan (1989), Prodigious submarine landslides on the Hawaiian ridge, J. Geophys. Res., 94, 17,465-17,484.

Oehler, J. F., P. Labazuy, and J. F. Lenat (2004), Recurrence of major flanklandslides during the last 2 Ma-history of Reunion Island, Bull. Volcanol., 66, 585-598.

Perret, F. (1937), The Eruption of Mt. Pelée 1929-1932, Carnegie Inst. Washington Publ., 458, 126 pp.

Pinel, V., and C. Jaupart (2000), The effect of edifice load on magma ascent beneath a volcano, Philos. Trans. R. Soc. London, Ser. A, 358, $1515-$ 1532 .

Reid, M. E., T. W. Sisson, and D. L. Brien (2001), Volcano collapse promoted by hydrothermal alteration and edifice shape, Mount Rainier, Washington, Geology, 29, 779-782.

Reid, R. P., S. N. Carey, and D. R. Ross (1996), Late Quaternary sedimentation in the Lesser Antilles island arc, Geol. Soc. Am. Bull., 108, 78100.

Robertson, R. E. A. (2005), Grenada, in Volcanic Atlas of the Lesser Antilles, edited by J. M. Lindsay et al., pp. 49-66, Univ. of the West Indies, Seismic Res. Unit, Trinidad.

Robertson, R. E. A., W. P. Aspinall, R. A. Herd, G. E. Norton, R. S. J. Sparks, and S. R. Young (2000), The 1995-98 eruption of Soufrière Hills volcano, Montserrat, Philos. Trans. R. Soc. London, Ser. A, 358, 16191637.

Robson, G. R., and J. F. Tomblin (1966), Catalogue of the active volcanoes and Solfatara fields of the West Indies, in Catalogue of the Active Volca- noes of the World including Solfatara Fields, part XX, pp.1-56, Int. Assoc. of Volcanol., Rome.

Roobol, M. J., and A. L. Smith (1998), Pyroclastic stratigraphy of the Soufrière Hills volcano, Montserrat: Implications for the present eruption, Geophys. Res. Lett., 25, 3393-3396.

Roobol, M. J., J. V. Wright, and A. L. Smith (1983), Calderas or gravityslide structures in the Lesser Antilles Island Arc?, J. Volcanol. Geotherm. Res., 19, 121-134.

Samper, A., X. Quidelleur, J.-C. Komorowski, and G. Boudon (2004), Timing of effusive volcanism within the whole Basse Terre Island (Guadeloupe, French West Indies) from new K-Ar Cassignol-Gillot ages, Geophys. Res. Abstr, 6, 00931.

Samper, A., X. Quidelleur, D. Mollex, and P. Lahitte (2007), Timing of effusive volcanism and collapse events within an oceanic arc island: Basse-Terre, Guadeloupe archipelago (Lesser Antilles Arc), Earth Planet. Sci. Lett., 258, 175-191, doi:10.1016/j.EPSL.2007.03.030.

Shepherd, J. B., W. Aspinall, K. Rowley, J. Pereira, H. Sigurdsson, R. Fiske, and J. Tomblin (1979), The eruption of the Soufrière volcano, St. Vincent, April-June 1979, Nature, 282, 24-28.

Siebert, L. (1984), Large volcanic debris avalanches: Characteristics of source areas, deposits, and associated eruptions, J. Volcanol. Geotherm. Res., 22, 163-197.

Sigurdsson, H., R. S. J. Sparks, S. N. Carey, and T. C. Huang (1980), Volcanogenic sedimentation in the Lesser Antilles Arc, J. Geol., 88, $523-540$.

Smith, M. S., and J. B. Shepherd (1993), Preliminary investigations of the tsunami hazard of Kick 'em Jenny submarine volcano, Nat. Hazards, 7 , $257-277$.

Smith, W. H. F., and D. T. Sandwell (1997), Global sea floor topography from satellite altimetry and ship depth soundings, Science, 227, 19561962 .

Sparks, R. S. J., and S. R. Young (2002), The eruption of Soufrière Hills Volcano, Montserrat: Overview of scientific results, in The Eruption of Soufrière Hills Volcano, Montserrat, From 1995 to 1999, edited by T. H. Druitt and B. P. Kokelaar, Mem. Geol. Soc. London, 21, 45-69.

Sparks, R. S. J., J. Barclay, E. S. Calder, R. A. Herd, J.-C. Komorowski, R. Luckett, G. E. Norton, L. Ritchie, B. Voight, and A. W. Woods (2002), Generation of a debris avalanche and violent pyroclastic density current: The Boxing Day eruption of 26 december 1997 at the Soufrière Hills Volcano, Montserrat, in The Eruption of Soufrière Hills Volcano, Montserrat, From 1995 to 1999 , edited by T. H. Druitt and B. P. Kokelaar, Mem. Geol. Soc. London, 21, 409-434.

Tomblin, J. F. (1965), The geology of the Soufrière volcanic centre, St Lucia, in Transactions of the Fourth Caribbean Geological Conference, pp. 367-376, Caribbean Print., Trinidad.

Urgeles, R., M. Canals, J. Baraza, B. Alonso, and D. Masson (1997), The most recent megalandslides of the Canary Islands: El Golfo debris avalanche and Canary debris flow, west El Hierro Island, J. Geophys. Res., 102, 20,305-20,323.

Vincent, P. M., J. L. Bourdier, and G. Boudon (1989), The primitive volcano of Mount Pelée: Its construction and partial destruction by flank collapse, J. Volcanol. Geotherm. Res., 38, 1-15.

Voight, B., J.-C. Komorowski, G. E. Norton, A. B. Belousov, M. Belousova, G. Boudon, P. W. Francis, W. Franz, P. Heinrich, R. S. J. Sparks, and S. R. Young (2002), The 26 December (Boxing Day) 1997 sector collapse and debris avalanche at Soufrière Hills Volcano, Montserrat, in The Eruption of Soufrière Hills Volcano, Montserrat, From 1995 to 1999, edited by T. H. Druitt and B. P. Kokelaar, Mem. Geol. Soc. London, 21, 363-407.

Wadge, G. (1985), Morne Patates volcano, southern Dominica, Lesser Antilles, Geol. Mag., 122(3), 253-260.

Wadge, G., and M. C. Isaacs (1988), Mapping the volcanic hazards from Soufrière Hills volcano, Montserrat, West Indies using an image processor, J. Geol. Soc., 145, 541-551.

Watters, R. J., D. R. Zimbelman, S. D. Bowman, and J. K. Crowley (2000), Rock mass strength assessment and significance to edifice stability, Mount Rainier and Mount Hood, Cascade range volcanoes, Pure Appl. Geophys., 157, 957-976.

Watts, A. B., and D. G. Masson (1995), A giant landslide on the north flank of Tenerife, Canary Islands, J. Geophys. Res., 100, 24,487-24,498.

Westercamp, D., P. Andreieff, P. Bouysse, S. Cottez, and R. Ballistini (1989), Notice explicative, carte géol. France (1/50 000), feuille Martinique, 246 pp., Bur. de Rec. Géol. et Minières, Orléans, France.

Wohletz, K., G. Heiken, M. Ander, F. Goff, F.-D. Vuataz, and G. Wadge (1986), The Qualibou Caldera, St. Lucia, West Indies, J. Volcanol. Geotherm. Res., 27, 77-115.

Wright, J. V., M. J. Roobol, A. L. Smith, R. S. J. Sparks, S. A. Brazier, W. I. Rose, and H. Sigurdsson (1984), Late quaternary explosive silicic volcanism on St. Lucia, West Indies, Geol. Mag., 121(1), 1-15. 
Young, S., B. Voight, J. Barclay, R. A. Herd, J.-C. Komorowski, A. D. Miller, R. S. J. Sparks, and R. C. Stewart (2002), Hazard implications of small-scale edifice instability and sector collapse: A case history from Soufrière Hills volcano, Montserrat, in The Eruption of Soufrière Hills Volcano, Montserrat, From 1995 to 1999, edited by T. H. Druitt and B. P. Kokelaar, Mem. Geol. Soc. London, 21, 349-361.

Zimbelman, D. R., R. J. Watters, I. R. Firth, G. N. Breit, and G. CarascoNunez (2004), Stratovolcano stability assessment methods and results from Citlaltépetl, Mexico, Bull. Volcanol., 66, 66-79.
Zlotnicki, J., G. Boudon, J.-P. Viodé, F. J-Delarue, A. Mille, and F. Bruère (1998), Hydrothermal circulations beneath Montagne Pelée inferred by self potential surveying. Structural and tectonic implications, J. Volcanol. Geotherm. Res., 84, 73-91.

G. Boudon, C. Deplus, J.-C. Komorowski, A. Le Friant, and M. P. Semet, Equipe Géologie des Systèmes Volcaniques, Institut de Physique du Globe de Paris, Case 89, 4 Place Jussieu, F-75252 Paris Cedex 05, France. (boudon@ipgp.jussieu.fr) 